
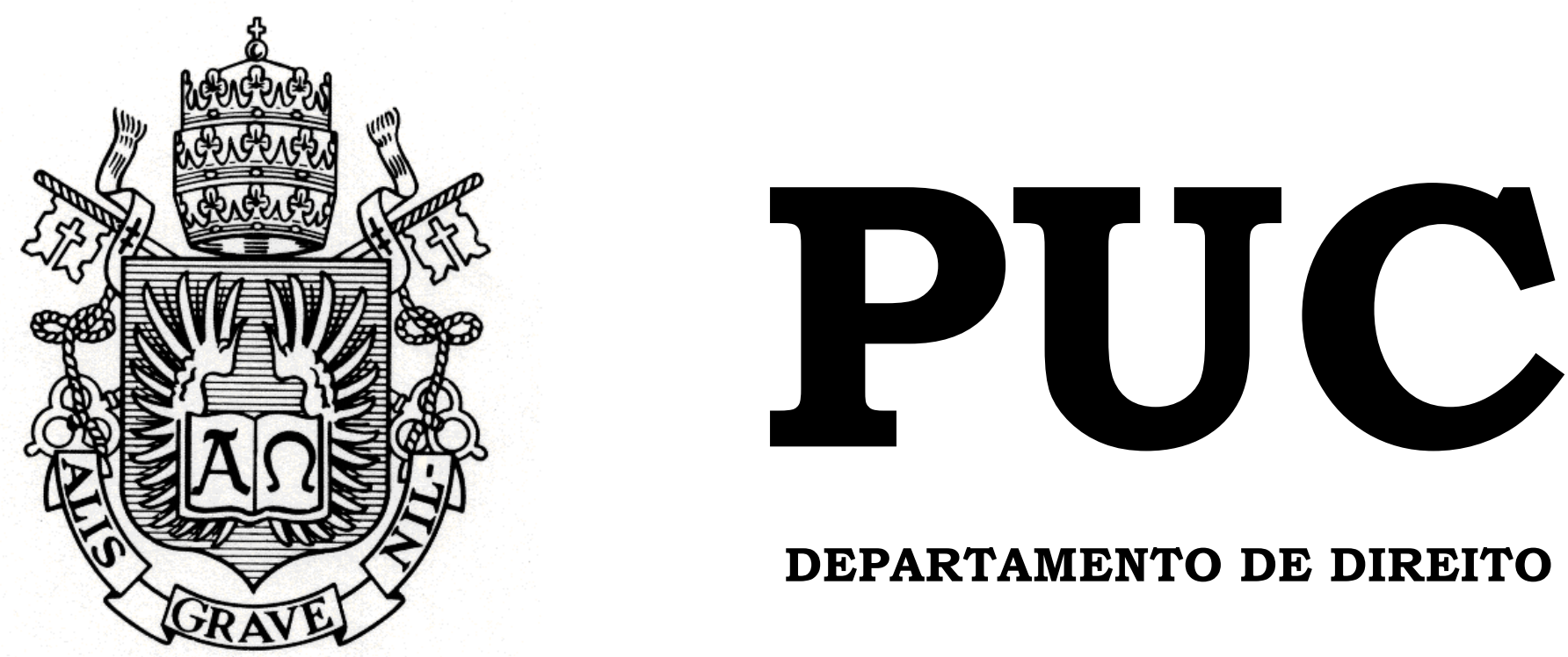

DEPARTAMENTO DE DIREITO

\title{
MULTIPARENTALIDADE: ALGUNS REFLEXOS DE SEU RECONHECIMENTO NO ÂMBITO DO DIREITO DE FAMÍLIA
}

por

ISABELA PINHEIRAL ELIAS

ORIENTADOR(A): Inês Alegria Rocumback 2017.2

PONTIFÍCIA UNIVERSIDADE CATÓLICA DO RIO DE JANEIRO RUA MARQUÊS DE SÃO VICENTE, 225 - CEP 22453-900 RIO DE JANEIRO - BRASIL 


\section{MULTIPARENTALIDADE: ALGUNS REFLEXOS DE SEU RECONHECIMENTO NO ÂMBITO DO DIREITO DE FAMÍLIA}

por

ISABELA PINHEIRAL ELIAS

Monografia

apresentada

ao

Departamento de Direito da Pontificia Universidade Católica do Rio de Janeiro (PUC-Rio) para a obtenção do Título de Bacharel em Direito.

Orientador(a): Inês Rocumback 


\section{AGRADECIMENTOS}

Gostaria de agradecer, inicialmente, a todos que contribuíram para minha formação e que, de alguma forma, me auxiliaram ao longo dessa jornada.

Agradeço à minha orientadora, Professora Inês Alegria Rocumback, por toda a atenção e suporte na elaboração deste trabalho.

Aos amigos que conquistei ao longo da faculdade e me acompanharam durante todo percurso, alegrando o meu dia a dia, os quais pretendo levar para o resto da vida.

Ao meu namorado e melhor amigo, Gustavo, que acompanhou toda minha trajetória pelos cinco anos de faculdade, com seu companheirismo e paciência, sempre me ajudando nos momentos mais difíceis.

Por fim e, principalmente, à minha família, em especial meu pai, Ricardo, e minha mãe, Luciane, por todo amor e apoio conferido ao longo de toda minha vida, sem os quais não seria possível alcançar os meus objetivos. São meu porto seguro, minha inspiração, meu eterno agradecimento a eles. 


\section{RESUMO}

O presente trabalho tem como objetivo analisar o instituto da multiparentalidade, ou seja, o reconhecimento de múltiplos vínculos de filiação em relação a um só filho, o que se demonstra possível dentro de um contexto plural de entidades familiares. Para tanto, analisamos a evolução das famílias, bem como dos princípios constitucionais que permitem sua admissão à luz do ordenamento jurídico brasileiro, como a dignidade da pessoa humana, a igualdade de filiação, a afetividade, dentre outros. Abordamos ainda a possibilidade de uma dupla filiação registral e as consequências do reconhecimento de uma multiparentalidade no âmbito do Direito de Família, refletindo acerca de como se adaptariam a esse fenômeno institutos como o exercício do poder familiar, os alimentos e o direito de guarda e visitação, previstos na legislação sob a ótica de famílias tipicamente biparentais. Examinamos, por fim, o recente caso julgado pelo Supremo Tribunal Federal, através do Recurso Extraordinário $\mathrm{n}^{\circ}$ 898.060/SC, onde expressamente foi admitida a possibilidade jurídica da multiparentalidade.

PALAVRAS-CHAVE: Multiparentalidade, Direito de Família, Princípios, Filiação, Socioafetividade, Registro, Poder Familiar, Alimentos, Guarda,

$\begin{array}{lllll}\text { Visitação, } & \text { Recurso } & \text { Extraordinário } & \mathrm{n}^{\circ} & 898.060 / \mathrm{SC} \text {. }\end{array}$ 


\section{SUMÁRIO}

INTRODUÇÃO

1. A EVOLUÇÃO DAS ENTIDADES FAMILIARES NO DIREITO

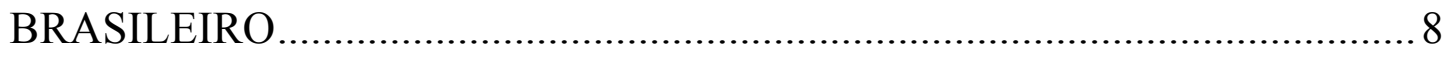

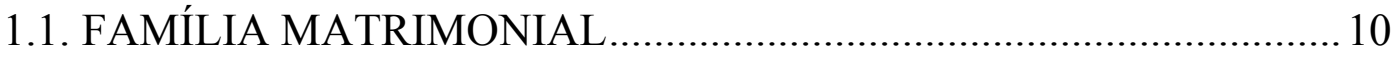

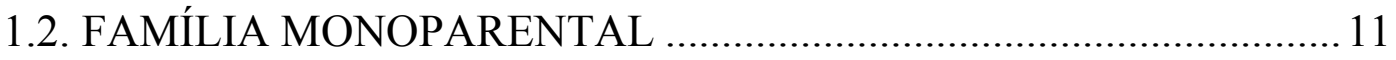

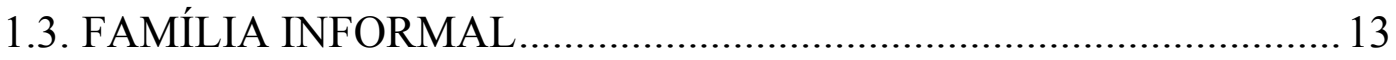

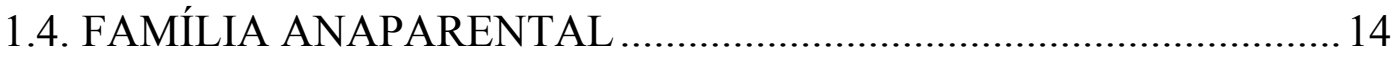

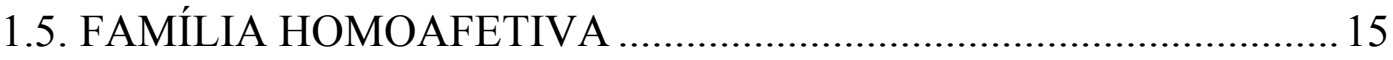

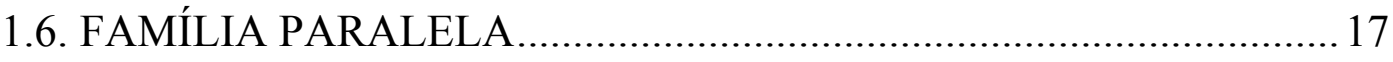

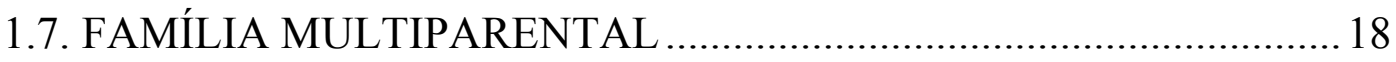

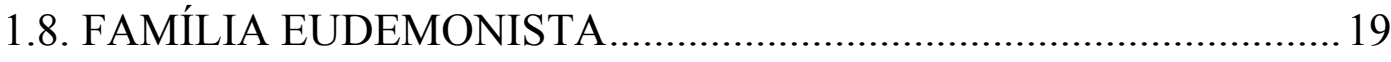

2. PRINCÍPIOS EMBASADORES DA MULTIPARENTALIDADE ............21

2.1. PRINCÍPIO DA DIGNIDADE DA PESSOA HUMANA ......................22

2.2. PRINCÍPIO DO PLANEJAMENTO FAMILIAR E DA

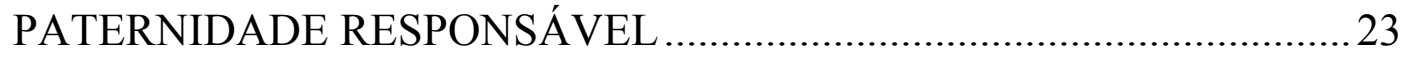

2.3. PRINCÍPIO DA IGUALDADE DE FILIAÇÃO ..................................24

2.4. PRINCÍPIO DO PLURALISMO FAMILIAR ….....................................26

2.5. PRINCÍPIO DA PROTEÇÃO INTEGRAL E DO MELHOR INTERESSE DA CRIANÇA E DO ADOLESCENTE ..............................27

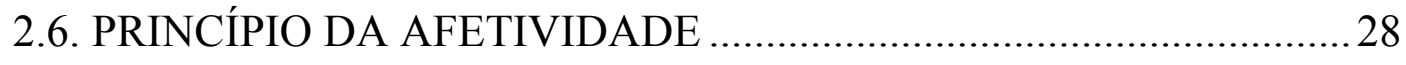

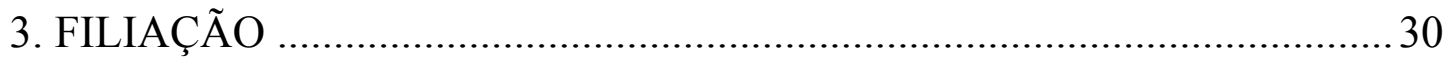

3.1. NOÇÕES GERAIS E TENTATIVA CONCEITUAL ….........................30

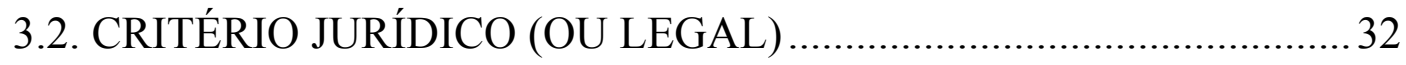

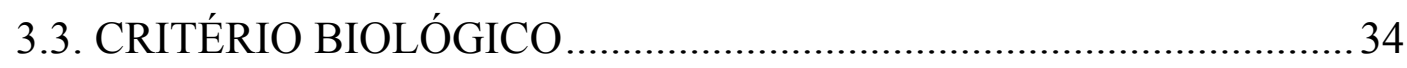

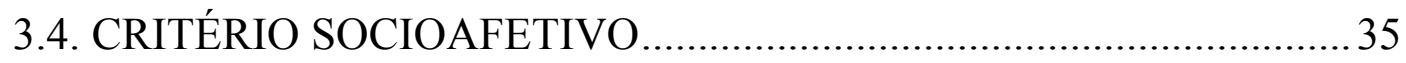

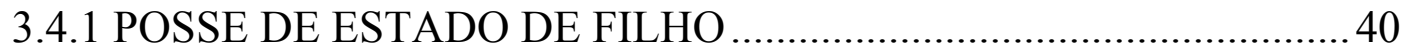


4. MULTIPARENTALIDADE

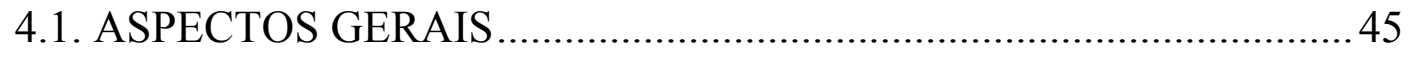

4.2. CONCOMITÂNCIA DA FILIAÇÃO BIOLÓGICA E

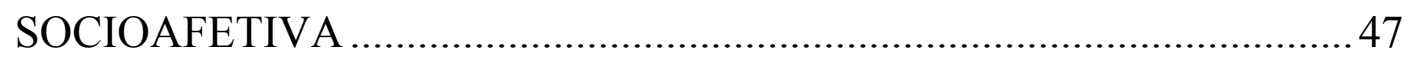

4.3. POSSIBILIDADE DE DUPLA FILIAÇÃO REGISTRAL ....................48

5. ALGUNS REFLEXOS DA MULTIPARENTALIDADE NO DIREITO DE

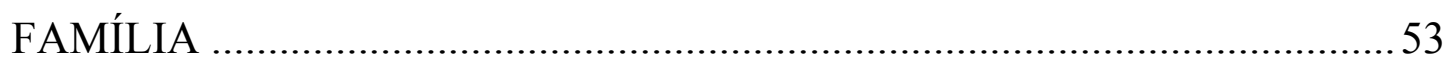

5.1. EXERCÍCIO DO PODER FAMILIAR …............................................. 54

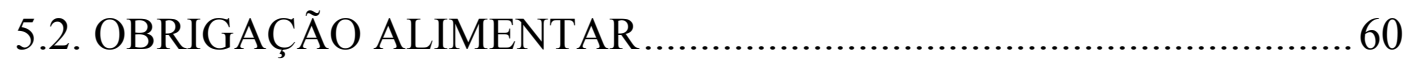

5.3. FIXAÇÃO DE GUARDA E DIREITO DE VISITAÇÃO......................64

6. ANÁLISE JURISPRUDENCIAL DO RECURSO EXTRAORDINÁRIO

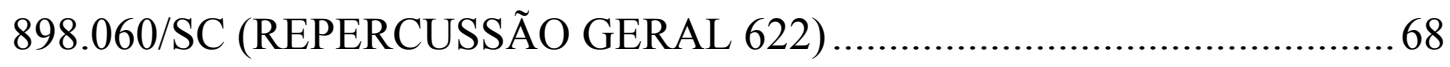

6.1. RECONHECIMENTO JURÍDICO DA AFETIVIDADE ....................73 6.2. IGUAL GRAU DE HIERARQUIA JURÍDICA DOS VÍNCULOS BIOLÓGICO E SOCIOAFETIVO............................................................ 74

6.3. POSSIBILIDADE JURÍDICA DA MULTIPARENTALIDADE .........76 6.4. POSSÍVEIS REFLEXOS DO JULGAMENTO .................................. 77

CONCLUSÃO

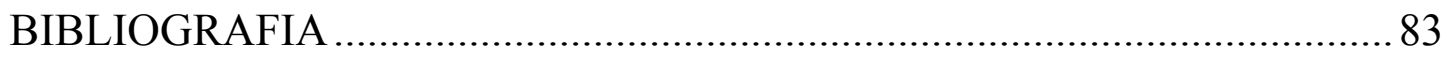




\section{INTRODUÇÃO}

O presente trabalho pretende analisar a possibilidade do reconhecimento da multiparentalidade e de seus principais reflexos dentro do âmbito do Direito de Família, em razão da pertinência que essa discussão representa na sociedade atual, caracterizada por uma pluralidade de entidades familiares.

O Direito de Família é um ramo em constante evolução e que não pode permanecer estagnado frente às necessidades sociais que se apresentam, sempre devendo agir para assegurar a máxima observância à dignidade e realização pessoal daqueles que integram uma relação familiar.

É cada vez mais comum nos depararmos com famílias que rompem as esferas tidas por tradicionais, baseadas no modelo essencialmente matrimonial e biparental, passando a predominar atualmente uma concepção plural de família, de forma a tutelar uma infinidade de arranjos familiares nutridos, primordialmente, pela afetividade entre seus membros.

Assim, será feita uma análise da evolução dos diferentes modelos familiares que foram sendo desenvolvidos e adaptados às necessidades demonstradas no progresso social, destacando a família multiparental também como uma entidade familiar, merecedora de idêntico status perante a sociedade e o próprio Estado.

Em um segundo momento, passaremos pela exposição dos princípios constitucionais que norteiam a interpretação no âmbito do Direito de Família e que permitem o reconhecimento da multiparentalidade (ou pluriparentalidade) como um núcleo familiar ensejador de especial proteção estatal, tal qual os demais.

Através do terceiro capítulo procuramos esclarecer alguns conceitos básicos concernentes à filiação, apresentando algumas noções gerais para a 
compreensão do tema, bem como abordando os três diferentes critérios de filiação, quais sejam: jurídico (ou legal), biológico e afetivo.

Isso porque a admissibilidade do instituto da multiparentalidade perpassa justamente pela possibilidade de coexistência desses múltiplos vínculos de filiação, podendo um mesmo filho possuir mais de um pai e/ou mais de uma mãe, decorrentes de diferentes critérios filiatórios concomitantes.

Em seguida, faremos uma análise mais aprofundada quanto ao instituto da pluriparentalidade propriamente, quando serão analisados os seus principais aspectos, quanto à concomitância das filiações biológica e socioafetiva, além da possibilidade de uma dupla filiação registral.

Dedicamos também um capítulo à discussão de alguns de seus reflexos no âmbito do Direito de Família, optando-se por aprofundar na repercussão que o reconhecimento desta nova entidade familiar representaria quanto ao exercício do poder familiar, à obrigação alimentar e ao direito de guarda e visitação a serem exercidos por múltiplos pais.

Por fim, analisaremos o recente caso emblemático julgado pelo Supremo Tribunal Federal no Recurso Extraordinário $n^{\circ}$ 898.060/SC, onde foi expressamente admitida a possibilidade da multiparentalidade, além de reconhecida juridicamente a afetividade e o direito à busca da felicidade, o que representou um grande avanço para a sociedade como um todo na efetivação da plena realização pessoal e da dignidade humana. 


\section{A EVOLUÇÃO DAS ENTIDADES FAMILIARES NO DIREITO BRASILEIRO}

A atual Constituição da República Federativa do Brasil, de 1988, consagrou em seu artigo $226^{1}$ uma multiplicidade de núcleos familiares, rompendo com a tradicional unicidade familiar, baseada no matrimônio, anteriormente vista como a única forma possível de se reconhecer uma família.

Cumpre ressaltar que o referido artigo não exaure os grupamentos familiares ao se referir expressamente apenas à família matrimonial, monoparental e união estável, uma vez que a interpretação sistemática dos princípios constitucionais que norteiam o Direito de Família permite a conclusão de que todo e qualquer núcleo familiar baseado no afeto merece especial proteção do Estado.

Como bem assevera Rolf Madaleno², "não é admissível preordenar espécies estanques de unidade familiar e destiná-las como emissárias únicas da proteção estatal", já que a sociedade acolhe outros modelos familiares e não somente aqueles exemplificados de maneira expressa no texto constitucional.

\footnotetext{
${ }^{1}$ Art. 226. A família, base da sociedade, tem especial proteção do Estado.

$\S 1^{\circ} \mathrm{O}$ casamento é civil e gratuita a celebração.

$\S 2^{\circ} \mathrm{O}$ casamento religioso tem efeito civil, nos termos da lei.

$\S 1^{\circ} \mathrm{O}$ casamento é civil e gratuita a celebração.

$\S 2^{\circ} \mathrm{O}$ casamento religioso tem efeito civil, nos termos da lei.

$\S 3^{\circ}$ Para efeito da proteção do Estado, é reconhecida a união estável entre o homem e a mulher como entidade familiar, devendo a lei facilitar sua conversão em casamento.

$\S 4^{\circ}$ Entende-se, também, como entidade familiar a comunidade formada por qualquer dos pais e seus descendentes.

$\S 5^{\circ}$ Os direitos e deveres referentes à sociedade conjugal são exercidos igualmente pelo homem e pela mulher.

$\S 6^{\circ} \mathrm{O}$ casamento civil pode ser dissolvido pelo divórcio.

$\S 7^{\circ}$ Fundado nos princípios da dignidade da pessoa humana e da paternidade responsável, o planejamento familiar é livre decisão do casal, competindo ao Estado propiciar recursos educacionais e científicos para o exercício desse direito, vedada qualquer forma coercitiva por parte de instituições oficiais ou privadas.

$\S 8^{\circ} \mathrm{O}$ Estado assegurará a assistência à família na pessoa de cada um dos que a integram, criando mecanismos para coibir a violência no âmbito de suas relações.

${ }^{2}$ MADALENO, Rolf. Curso de Direito de Família. $4^{\mathrm{a}}$ ed.. Rio de Janeiro: Editora Forense Ltda., 2011.p. 7.
} 
Isso porque a sociedade encontra-se em constante evolução, tal qual o conceito de família, que não poderia deixar de acompanhar os avanços e os novos valores decorrentes do progresso humano para abarcar uma pluralidade de arranjos familiares que caracteriza a atual realidade social.

Conforme lecionam Cristiano Chaves e Nelson Rosenvald ${ }^{3}$, a família contemporânea impõe um novo modelo familiar, baseado no afeto, na solidariedade recíproca entre os seus membros e na construção individual da felicidade, visando à garantia da plena dignidade humana.

Segundo Paulo Lôbo $^{4}$, a família brasileira atual teria como função precípua a realização pessoal da afetividade, em um ambiente de convivência e solidariedade recíproca entre seus membros.

Nesse mesmo sentido posiciona-se Maria Berenice Dias ${ }^{5}$ quando afirma ter havido uma "repersonalização das relações familiares", visando atender cada vez mais aos interesses das pessoas envolvidas do que aos interesses patrimoniais, privilegiando a dignidade da pessoa humana e a presença do afeto, solidariedade, lealdade, confiança, respeito e amor.

Este capítulo busca, portanto, analisar essa variedade de entidades familiares que foram sendo desenvolvidas e paulatinamente reconhecidas na doutrina e jurisprudência brasileiras, caracterizando o permanente processo de mudança inerente à conceituação de família.

\footnotetext{
${ }^{3}$ FARIAS, Cristiano Chaves de; ROSENVALD, Nelson. Curso de Direito Civil: Vol. 6 Famílias. $7^{\mathrm{a}}$ ed.. São Paulo: Atlas, 2015. p. 6.

${ }^{4}$ LÔBO, Paulo. Direito Civil: Famílias. 5a ed.. São Paulo: Saraiva, 2014. p. 17.

${ }^{5}$ DIAS, Maria Berenice. Manual de Direito das Famílias. $10^{\mathrm{a}}$ ed.. São Paulo: Revista dos Tribunais, 2015. p. 34.
} 


\subsection{FAMÍLIA MATRIMONIAL}

A família matrimonial corresponde àquela tradicional concepção de família originada do casamento, sendo esta a única entidade familiar anteriormente reconhecida no ordenamento jurídico.

Em sua origem, o casamento era visto como instituição através da qual era constituída a família, pouco importando os laços afetivos e a felicidade pessoal dos seus membros, prevalecendo a manutenção do vínculo conjugal a todo custo.

Antes do advento da Constituição de 1988, o casamento era a única forma de família ensejadora da proteção estatal, enquanto as demais reuniões familiares, hoje admitidas, eram consideradas ilegítimas e, por conseguinte, não eram protegidas pela ordem jurídica brasileira.

Esse cenário foi modificado, segundo Chaves e Rosenvald ${ }^{6}$, com a denominada "cláusula geral de inclusão constitucional" constante do supramencionado artigo 226 da Carta Magna, passando a ser protegido todo e qualquer núcleo familiar, substituindo a exclusividade do matrimônio que, atualmente, é apenas mais uma forma de constituição de entidade familiar.

No mais, alterou-se também a sua posição institucional, deixando de ser o objetivo central de vida das pessoas, para ser instrumento, meio de desenvolvimento de sua personalidade em busca da plena realização pessoal, reconhecendo-se a sua dissolubilidade e a ausência de exclusividade.

A família matrimonial, portanto, fundada no casamento, pode ser caracterizada como uma união solene, fruto da liberdade de escolha das partes $^{7}$, no intuito de estabelecer uma comunhão de vida entre os cônjuges.

\footnotetext{
${ }^{6}$ FARIAS, Cristiano Chaves de; ROSENVALD, Nelson. Op. Cit., p. 58.

${ }^{7}$ Ainda que se trate de uma liberdade mitigada, uma vez que condicionada à observância de normas de ordem pública.
} 
Além disso, conforme anteriormente ressaltado, já é amplamente reconhecida a possibilidade de sua dissolução, seja de maneira bilateral ou até mesmo unilateralmente, sendo dispensável a aquiescência do outro cônjuge para tal.

Ressalte-se, por oportuno, que a Emenda Constitucional $n^{\circ}$ 66/2010, dando prevalência à realização pessoal e autonomia das partes, facilitou o processo de dissolução conjugal. Sendo assim, atualmente o divórcio não está sujeito a qualquer requisito legal prévio, seja demonstração de culpa, lapso temporal ou qualquer outro óbice, conferindo-se plena liberdade de escolha às partes na decisão de permanecerem ou não casadas, não podendo o Estado criar qualquer obstáculo que dificulte o término do vínculo conjugal.

No que tange aos avanços jurisprudenciais, destaca-se que não mais a diversidade de sexos se apresenta como pressuposto ao casamento civil, tendo sido reconhecido pelo Superior Tribunal de Justiça a possibilidade de casamento homoafetivo, após o reconhecimento pelo Supremo Tribunal Federal das uniões homoafetivas, com fundamento nos princípios constitucionais da igualdade, da não discriminação, dignidade da pessoa humana, pluralismo e livre planejamento familiar, dentre outros. ${ }^{8}$

\subsection{FAMÍLIA MONOPARENTAL}

A família monoparental é expressamente reconhecida no texto constitucional, no $\S 4^{\circ}$ do artigo 226, quando se refere à "comunidade formada por qualquer dos pais e seus descendentes".

As famílias monoparentais são situações cada vez mais presentes na realidade social, onde há a formação de um novo núcleo familiar seja a partir de uma dissolução conjugal, seja no caso de pais solteiros, que optam por

\footnotetext{
${ }^{8}$ Superior Tribunal de Justiça, Recurso Especial n ${ }^{\circ} 1.183 .378 /$ RS, Rel. Min. Luís Felipe Salomão, Brasília, 25 out. 2011.
} 
constituírem uma união livre ou de fato criarem sozinhos seus filhos ou ainda viúvos que precisam sustentar os encargos de uma família sozinhos, razão pela qual são entidades familiares que possuem estruturas mais frágeis. ${ }^{9}$

Além de demandar a prestação de alimentos entre ascendentes e descendentes, reciprocamente, também impõe um dever de assistência moral, de administração do patrimônio dos filhos e de guarda, sustento e educação. ${ }^{10}$

Segundo destaca Maria Berenice Dias ${ }^{11}$, não seria sequer pré-requisito para o reconhecimento desse núcleo familiar a existência de relação de parentesco ou a menoridade dos descendentes, desde que existente relação de guarda. Isso porque, conforme ressalta a autora, é característica da monoparentalidade a transgeracionalidade, ou seja, exige-se apenas que haja diferença de gerações entre os membros, sem que exista qualquer relacionamento sexual entre eles, independentemente de serem parentes ou ser o descendente maior de idade.

Conforme destacado, a família monoparental pode ser originada do divórcio, quando um dos genitores fica com a guarda do filho e passa a constituir uma nova entidade familiar, além da adoção, uma vez que inexistem impedimentos à adoção por pessoa solteira, desde que em atenção ao melhor interesse da criança.

Ademais, por escolha pessoal pode ainda ser constituída a monoparentalidade a partir de uniões livres ou ainda através de técnicas de inseminação artificial, práticas essas cada vez mais presentes e corriqueiras na sociedade atual, onde o empoderamento feminino fez com que se

\footnotetext{
${ }^{9}$ FARIAS, Cristiano Chaves de; ROSENVALD, Nelson. Op. Cit., p. 78.

${ }^{10}$ Ibid. p. 77.

${ }^{11}$ DIAS, Maria Berenice. Op. Cit., p. 291.
} 
desvinculasse a ideia de reprodução do matrimônio, sendo muito comuns hoje em dia as chamadas "produções independentes". 12

\subsection{FAMÍLIA INFORMAL}

Conforme destacado anteriormente, o conceito de família passou por um processo de evolução para se adaptar às necessidades sociais e a família informal representa justamente o resultado dessa realidade, cada vez mais presente, de relações extramatrimoniais.

Anteriormente, tais relações informais eram absolutamente marginalizadas e rejeitadas pela jurisprudência, conhecidas como relacionamentos adulterinos ou concubinários, equiparados a uma relação de trabalho e concedendo-se à concubina indenização por serviços domésticos ou ainda, quando provada sua contribuição patrimonial, aplicava-se o direito comercial e reconhecia-se uma sociedade de fato. ${ }^{13}$

Essa situação perdurou até a Constituição de 1988, quando esse denominado concubinato foi afirmado como entidade familiar e passou a se chamar união estável. ${ }^{14}$

Conforme lecionam Chaves e Rosenvald ${ }^{15}$, o concubinato que foi alçado à condição de entidade familiar através da atual união estável seria o chamado "concubinato puro" ${ }^{16}$, ou seja, aquele no qual não há qualquer impedimento às pessoas casarem e sim uma escolha do casal em manterem essa união informal.

\footnotetext{
12 Ibid. p. 293.

13 Ibid. p. 136.

${ }^{14}$ MADALENO, Rolf. Op. Cit., p. 8.

${ }^{15}$ FARIAS, Cristiano Chaves de; ROSENVALD, Nelson. Op. Cit., p. 441.

16 À guisa de informação, o denominado "concubinato impuro" corresponderia àquele formado por pessoas que por algum motivo não podem casar e, portanto, não estaria abrigado como entidade familiar.
} 
Dessa forma, o texto constitucional atual veio proteger, de maneira expressa, essas relações afetivas desprovidas de formalidades, mas que ensejam idêntica proteção estatal que é dispendida às uniões matrimoniais. ${ }^{17}$

\subsection{FAMÍLIA ANAPARENTAL}

A denominada família anaparental, por sua vez, também reconhecida como entidade familiar, diferencia-se da família monoparental em razão da inexistência de hierarquia de gerações entre os seus integrantes.

Tal qual a família monoparental, os laços familiares estabelecidos na anaparentalidade estão desvinculados de qualquer interesse sexual entre seus membros, uma vez que se trata, via de regra, de uma família constituída entre irmãos, apesar de também poder ser estabelecida entre outros parentes ou até entre pessoas sem laço de consanguinidade ${ }^{18}$, constituindo-se um núcleo familiar com todos os efeitos daí decorrentes.

Assim, conforme dispõe Madaleno ${ }^{19}$, trata-se de núcleo familiar que dispensa tanto uma relação vertical de ascendência quanto a presença de um vínculo de parentesco, desde que exista entre eles uma identidade de propósitos.

Tal entidade familiar já é amplamente reconhecida na jurisprudência como modelo familiar, como no seguinte julgado:

"CIVIL. PROCESSUAL CIVIL. RECURSO ESPECIAL. ADOÇÃO PÓSTUMA.
VALIDADE. ADOÇÃO CONJUNTA. PRESSUPOSTOS. FAMÍLIA
ANAPARENTAL. POSSIBILIDADE. Ação anulatória de adoção post mortem,
ajuizada pela União, que tem por escopo principal sustar o pagamento de benefícios
previdenciários ao adotado - maior interdito -, na qual aponta a inviabilidade da adoção
post mortem sem a demonstração cabal de que o de cujus desejava adotar e, também, a
impossibilidade de ser deferido pedido de adoção conjunta a dois irmãos. A redação do
art. $42, \S 5^{\circ}$, da Lei $8.069 / 90$ - ECA -, renumerado como $\S 6^{\circ}$ pela Lei $12.010 / 2009$, que

\footnotetext{
${ }^{17}$ Art. 226. A família, base da sociedade, tem especial proteção do Estado.

$\S 3^{\circ}$ Para efeito da proteção do Estado, é reconhecida a união estável entre o homem e a mulher como entidade familiar, devendo a lei facilitar sua conversão em casamento.

${ }^{18}$ DIAS, Maria Berenice. Op. Cit., p. 291.

${ }^{19}$ MADALENO, Rolf. Op. Cit., p. 10.
} 
é um dos dispositivos de lei tidos como violados no recurso especial, alberga a possibilidade de se ocorrer a adoção póstuma na hipótese de óbito do adotante, no curso do procedimento de adoção, e a constatação de que este manifestou, em vida, de forma inequívoca, seu desejo de adotar. Para as adoções post mortem, vigem, como comprovação da inequívoca vontade do de cujus em adotar, as mesmas regras que comprovam a filiação socioafetiva: o tratamento do menor como se filho fosse e o conhecimento público dessa condição. $\mathrm{O}$ art. $42, \S 2^{\circ}$, do ECA, que trata da adoção conjunta, buscou assegurar ao adotando a inserção em um núcleo familiar no qual pudesse desenvolver relações de afeto, aprender e apreender valores sociais, receber e dar amparo nas horas de dificuldades, entre outras necessidades materiais e imateriais supridas pela família que, nas suas diversas acepções, ainda constitui a base de nossa sociedade. A existência de núcleo familiar estável e a consequente rede de proteção social que podem gerar para o adotando, são os fins colimados pela norma e, sob esse prisma, o conceito de núcleo familiar estável não pode ficar restrito às fórmulas clássicas de família, mas pode, e deve, ser ampliado para abarcar uma noção plena de família, apreendida nas suas bases sociológicas. Restringindo a lei, porém, a adoção conjunta aos que, casados civilmente ou que mantenham união estável, comprovem estabilidade na família, incorre em manifesto descompasso com o fim perseguido pela própria norma, ficando teleologicamente órfã. Fato que ofende o senso comum e reclama atuação do interprete para flexibilizá-la e adequá-la às transformações sociais que dão vulto ao anacronismo do texto de lei. O primado da família socioafetiva tem que romper os ainda existentes liames que atrelam o grupo familiar a uma diversidade de gênero e fins reprodutivos, não em um processo de extrusão, mas sim de evolução, onde as novas situações se acomodam ao lado de tantas outras, já existentes, como possibilidades de grupos familiares. O fim expressamente assentado pelo texto legal colocação do adotando em família estável - foi plenamente cumprido, pois os irmãos, que viveram sob o mesmo teto, até o óbito de um deles, agiam como família que eram, tanto entre si, como para o então infante, e naquele grupo familiar o adotado se deparou com relações de afeto, construiu - nos limites de suas possibilidades - seus valores sociais, teve amparo nas horas de necessidade físicas e emocionais, em suma, encontrou naqueles que o adotaram, a referência necessária para crescer, desenvolverse e inserir-se no grupo social que hoje faz parte. Nessa senda, a chamada família anaparental - sem a presença de um ascendente -, quando constatado os vínculos subjetivos que remetem à família, merece o reconhecimento e igual status daqueles grupos familiares descritos no art. 42, § 2, do ECA. Recurso não provido." 20

(Grifo nosso)

\subsection{FAMÍLIA HOMOAFETIVA}

Apesar das famílias homoafetivas não serem expressamente reconhecidas na Constituição Federal, uma interpretação sistemática dos princípios constitucionais e do ordenamento jurídico como um todo permitem a sua

\footnotetext{
${ }^{20}$ Superior Tribunal de Justiça, Recurso Especial no 1.217.415/RS, Rel. Min. Nancy Andrighi, Brasília, 19 jun. 2012.
} 
compreensão como entidade familiar merecedora de especial proteção do Estado.

Dessa forma, dentre os preceitos constitucionais, é vedada na ordem jurídica brasileira qualquer discriminação ou preconceito por motivos de sexo, protegendo-se a dignidade da pessoa humana e a igualdade social, razão pela qual deve ser assegurada proteção às entidades familiares independentemente de sua orientação sexual, uma vez que não é este requisito essencial para que haja a tutela estatal das famílias.

Nesse sentido, já se posicionou a jurisprudência, tendo o Supremo Tribunal Federal reconhecido a natureza familiar das uniões homoafetivas, no julgamento da ADI $n^{\circ} 4277$ e ADPF $n^{\circ} 132^{21}$, produzindo todos os efeitos típicos de uma união estável, seja no âmbito patrimonial ou até mesmo existencial (é garantido ao casal homossexual, portanto, direito sucessório, previdenciário, obrigação alimentícia, adoção, dentre os demais direitos assegurados na hipótese de uma união estável entre homem e mulher).

Após esse posicionamento do Supremo Tribunal Federal a jurisprudência começou a admitir a conversão da união homoafetiva em casamento, até que o Superior Tribunal de Justiça foi além para admitir a realização do casamento civil homoafetivo de maneira direta, através do supramencionado Recurso Especial n $1.183 .378 / \mathrm{RS}$.

Em seguida, visando contribuir ainda mais ao progresso social e à igualdade de direitos, o Conselho Nacional de Justiça editou a Resolução ${ }^{\circ}$ $175 / 13^{22}$, proibindo a recusa de reconhecimento da união homoafetiva, de sua conversão em casamento e de sua própria celebração direta entre pessoas do mesmo sexo.

\footnotetext{
21 Supremo Tribunal Federal, ADPF n 132/RJ, Rel. Min. Ayres Britto, Brasília, 05 mai. 2011.

22 Conselho Nacional de Justiça. Resolução $n^{\circ} 175$ de 14 mai. 2013. Disponível em: <http://www.cnj.jus.br/busca-atos-adm?documento=2504>. Acesso em 30 mai. 2017.
} 


\subsection{FAMÍLIA PARALELA}

A família paralela (ou simultânea) corresponde àquela caracterizada pela concomitância de entidades familiares, seja por um matrimônio e uma união estável ou ainda duas ou mais uniões estáveis simultâneas.

São relações que se formam na realidade social, mas, majoritariamente, na doutrina e jurisprudência não se reconhece formalmente a existência de tais uniões paralelas, o que, segundo Dias ${ }^{23}$, afronta a dignidade dos seus membros e de eventuais filhos advindos dessas uniões.

Não existe entendimento pacificado, havendo doutrina mais conservadora que sustenta a inexistência de qualquer direito aos partícipes, fundamentandose, por exemplo, na monogamia e na impossibilidade de proteção estatal concomitante a mais de uma família.

Ocorre que tais argumentos, conforme bem assevera Dias, seriam descabidos quando se verifica que a monogamia é tão somente uma regra que visa coibir a formação de uma multiplicidade de relações matrimoniais, não devendo, entretanto, servir de "juízo prévio e geral de reprovabilidade contra formações conjugais plurais não constituídas sob sua égide". ${ }^{24}$

Sendo assim, negar reconhecimento e efeitos jurídicos às famílias paralelas representaria, além de uma ofensa à dignidade dos partícipes e de seus filhos, também uma chancela à infidelidade, uma vez que não haveria qualquer obrigação ao infiel, configurando um enriquecimento injustificável e deixando ao desamparo os demais membros envolvidos.

Conforme ressalta Maria Berenice Dias ${ }^{25}$, uma vez presentes os requisitos para a caracterização de união estável, ou seja, relacionamento público,

\footnotetext{
${ }^{23}$ DIAS, Maria Berenice. Op. Cit., p. 138.

${ }^{24}$ Ibid. p. 281.

${ }^{25}$ Ibid. p. 138.
} 
contínuo, duradouro e com a finalidade de constituir família, não se deve a ela negar reconhecimento por já existir outra entidade familiar concomitante. Destaca-se que a existência de uma entidade familiar não impede que ainda haja a finalidade de constituir outra família, não sendo pressuposto à sua configuração a fidelidade.

\subsection{FAMÍLIA MULTIPARENTAL}

A família multiparental é caracterizada por uma pluralidade de relações parentais, em razão do acúmulo de diferentes critérios de filiação, que pode ter origem em diferentes situações, apesar deste trabalho centrar seu estudo, primordialmente, na multiparentalidade que nasce da realidade das famílias reconstituídas.

Sendo assim, a multiparentalidade surge, muitas vezes, nesse contexto de recomposição afetiva de um casal, onde um ou ambos possuem filhos provenientes de casamentos ou uniões anteriores, formando uma nova entidade familiar da qual nascem novos vínculos afetivos.

Tal núcleo familiar apresenta uma extensa variedade de nomenclaturas pelas quais também é conhecida, como: família reconstruída, recomposta, mosaico ou pluriparental, e, segundo Dias ${ }^{26}$, essa infinidade de nomes demonstraria a presença de grande resistência ainda existente em aceitá-la como entidade familiar.

Apesar de ser realidade cada vez mais presente na sociedade atual, as famílias multiparentais não possuem regulamentação legal específica que fixe direitos e deveres aos seus integrantes, sendo seu reconhecimento apenas jurisprudencial e doutrinário e, ainda assim, pode-se dizer, incipiente.

\footnotetext{
${ }^{26}$ Ibid. p. 141.
} 
Mais adiante, em capítulos a ela inteiramente dedicados, será feita uma análise mais aprofundada especificamente dessa nova entidade familiar, que é objeto do presente estudo, quando serão destacados seus principais aspectos e características, bem como analisada a recente posição jurisprudencial firmada pelo Supremo Tribunal Federal acerca da possibilidade da pluriparentalidade.

\subsection{FAMÍLIA EUDEMONISTA}

A família eudemonista, por sua vez, surge nesse contexto para o qual a Constituição Federal de 1988 pareceu caminhar, no sentido de garantir o desenvolvimento pessoal de cada um dos integrantes de uma entidade familiar, visando não apenas respeitar a dignidade humana destes, mas também alcançar a sua felicidade individual plena.

$\mathrm{O}$ direito à busca da felicidade foi inclusive reconhecido pelo Supremo Tribunal Federal no julgamento do Recurso Extraordinário n 898.060/SC, que será posteriormente detalhado, o que, portanto, legitima a possibilidade de famílias eudemonistas, visto que seu núcleo existencial reside justamente na busca da felicidade.

O ilustre relator Ministro Luiz Fux chegou a afirmar no referido julgamento que o direito à busca da felicidade seria um postulado implícito no artigo $1^{\circ}$, inciso III da Constituição Federal e que protegeria o ser humano das tentativas estatais de "enquadrar a realidade familiar em modelos préconcebidos pela lei”,27, elevando os indivíduos à centralidade do ordenamento jurídico-político e reconhecendo sua liberdade e autodeterminação, de acordo com o que determina a concepção eudemonista de família, onde a família existiria em prol da realização pessoal e busca da felicidade de seus membros.

\footnotetext{
${ }^{27}$ Supremo Tribunal Federal, Recurso Extraordinário n ${ }^{\circ}$ 898.060/SC, Rel. Min. Luiz Fux. Brasília, 21 set. 2016. Íntegra do voto do relator. p. 11. Disponível em: < http://www.stf.jus.br/arquivo/cms/noticiaNoticiaStf/anexo/RE898060.pdf>. Acesso em 05 set. 2017.
} 
Conforme destaca $\operatorname{Dias}^{28}$, não se justifica uma excessiva ingerência estatal na vida das pessoas, como ocorria quando apenas o matrimônio era reconhecido como entidade familiar e os interesses patrimoniais protagonizavam, situação essa que foi e continua sendo objeto de progresso.

Atualmente, toda forma de união baseada no afeto pode e deve ser protegida pelo Estado, mas desde que isso não represente uma forma de limitar sua existência. Afinal, a família atual é agora "espaço de realização pessoal afetiva" ${ }^{29}$, identificada pela "comunhão de vida, de amor e de afeto no plano da igualdade, da liberdade, da solidariedade e da responsabilidade recíproca". ${ }^{30}$

Por fim, destaca-se que não se pretendeu pelo presente capítulo esgotar as infinidades de entidades familiares existentes, tampouco tratar de todos os seus aspectos, uma vez que, para tal, demandar-se-ia um estudo mais aprofundado especificamente de cada possível modalidade. Sendo assim, o que se buscou foi tão somente ressaltar alguns dos diversos tipos de núcleos familiares e suas particularidades que se demonstraram pertinentes ao presente estudo.

\footnotetext{
${ }^{28}$ DIAS, Maria Berenice. Op. Cit., p. 144.

${ }^{29}$ LÔBO, Paulo. Op. Cit., p. 23.

${ }^{30}$ LÔBO, Paulo apud DIAS, Maria Berenice. Op. Cit., p. 144.
} 


\section{PRINCÍPIOS EMBASADORES DA MULTIPARENTALIDADE}

Os princípios constitucionais norteiam a interpretação jurídica em todo o ordenamento jurídico, inclusive no âmbito do Direito de Família, de acordo com os valores neles estabelecidos.

Segundo Maria Berenice Dias ${ }^{31}$, existem princípios gerais, aplicáveis a todos os ramos do Direito, como é o caso da dignidade da pessoa humana, e existem princípios especiais, característicos do âmbito familiar, como é o caso da afetividade e da solidariedade.

Além disso, também existem princípios implícitos, ou seja, que não estão expressos no texto constitucional ou na legislação infraconstitucional, mas que decorrem de uma interpretação sistemática do ordenamento como um todo e que possuem igual hierarquia que os princípios explícitos.

A doutrina apresenta uma infinidade de princípios que regem as relações familiares, ou seja, a depender do autor são realizadas diferentes enumerações principiológicas.

Sendo assim, a seguir pretende-se destacar apenas alguns dos princípios fundamentais para a compreensão dessa nova entidade familiar, que é objeto de estudo do presente trabalho, sem, no entanto, ter a pretensão de esgotar todas as suas nuances, mas tão somente ressaltando seus principais aspectos que permitem fundamentar a multiparentalidade.

Para isso, foi feita uma análise do Recurso Extraordinário n ${ }^{\circ}$ 898.060/SC, destacando-se os princípios que podem ser extraídos do referido julgamento e que serviram de fundamento para o reconhecimento dessa forma de entidade familiar, conforme será exposto nos seguintes subcapítulos.

\footnotetext{
${ }^{31}$ DIAS, Maria Berenice. Op. Cit., p. 43.
} 


\subsection{PRINCÍPIO DA DIGNIDADE DA PESSOA HUMANA}

O princípio da dignidade da pessoa humana é princípio fundamental de um Estado Democrático de Direito, estatuído no artigo $1^{\circ}$, inciso III da Constituição Federal ${ }^{32}$ e elevado à "valor nuclear da ordem constitucional". ${ }^{33}$

Trata-se, conforme ressalta Caio Mário ${ }^{34}$, de "macroprincípio constitucional" do qual irradiam diversos subprincípios ou princípios implícitos.

Segundo destaca Dias ${ }^{35}$, a dignidade da pessoa humana se manifesta tanto como um limite à atuação estatal, quanto como um dever do Estado em atuar de maneira ativa para garantir a observância de igual dignidade às diferentes entidades familiares.

No julgamento do Recurso Extraordinário $n^{\circ}$ 898.060/SC, afirmou o relator Ministro Luiz Fux que

"o sobreprincípio da dignidade da pessoa humana, na sua dimensão de tutela da felicidade e realização pessoal dos indivíduos a partir de suas próprias configurações existenciais, impõe o reconhecimento, pelo ordenamento jurídico, de modelos familiares diversos da concepção tradicional." 36

Tal princípio legitima, portanto, a multiplicidade de uniões afetivas que surgem com a evolução da sociedade e que encontram seu fundamento de validade justamente na garantia da plena dignidade de seus integrantes.

Em outro momento, no supramencionado julgado, se sustenta ainda que a superação dos óbices legais em prol do desenvolvimento das famílias

\footnotetext{
${ }^{32}$ Art. $1^{\circ}$. A República Federativa do Brasil, formada pela união indissolúvel dos Estados e Municípios e do Distrito Federal, constitui-se em Estado Democrático de Direito e tem como fundamentos: III - a dignidade da pessoa humana;

${ }^{33}$ DIAS, Maria Berenice. Op. Cit., p. 44.

${ }^{34}$ PEREIRA, Caio Mário da Silva. Instituições de Direito Civil: Volume V Direito de Família. $23^{\mathrm{a}}$ ed.. Rio de Janeiro: Forense, 2015. p. 61.

${ }^{35}$ DIAS, Maria Berenice. Op. Cit., p. 45.

${ }^{36}$ Supremo Tribunal Federal, Recurso Extraordinário n ${ }^{\circ}$ 898.060/SC, Rel. Min. Luiz Fux. Brasília, 21 set. 2016. Íntegra do voto do relator. p. 17. Disponível em: < http://www.stf.jus.br/arquivo/cms/noticiaNoticiaStf/anexo/RE898060.pdf>. Acesso em 05 set. 2017.
} 
constituídas com base na afetividade seria corolário do princípio da dignidade da pessoa humana.

Isso porque "a família só faz sentido para o Direito a partir do momento em que ela é veículo funcionalizador da dignidade de seus membros."

Portanto, o princípio da dignidade da pessoa humana demanda um equilíbrio entre os valores coletivos da família e a dignidade individual de cada um de seus membros, num movimento de respeito recíproco e plena realização existencial de seus integrantes. ${ }^{38}$

\subsection{PRINCÍPIO DO PLANEJAMENTO FAMILIAR E DA PATERNIDADE RESPONSÁVEL}

Os princípios do planejamento familiar e da paternidade responsável encontram-se positivados no artigo $226, \S 7^{\circ}$, que estabelece plena liberdade ao casal decidir seu planejamento familiar, sendo apenas competência estatal a garantia dos recursos educacionais e científicos necessários.

O principal objetivo do planejamento familiar é, portanto, evitar a formação de núcleos familiares sem condições de sustento e manutenção, sendo de livre escolha do casal o planejamento familiar, vedando-se ao Estado qualquer intervenção coercitiva. ${ }^{39}$

No que tange à paternidade responsável, utilizada como fundamento ao reconhecimento da multiparentalidade, através do Recurso Extraordinário ${ }^{\circ}$ 898.060/SC, é necessário atentar para os deveres de assistência moral, afetiva, material e intelectual que os pais possuem em relação aos filhos.

Destacou-se no referido julgado que

“a paternidade responsável, enunciada expressamente no art. $226, \S 7^{\circ}$, da Constituição, na perspectiva da dignidade humana e da busca pela felicidade, impõe o

\footnotetext{
${ }^{37}$ PEREIRA, Caio Mário da Silva. Op. Cit., p. 63.

${ }^{38}$ LÔBO, Paulo. Op. Cit., p. 55.

${ }^{39}$ FARIAS, Cristiano Chaves de; ROSENVALD, Nelson. Op. Cit., p. 103.
} 
acolhimento, no espectro legal, tanto dos vínculos de filiação construídos pela relação afetiva entre os envolvidos, quanto daqueles originados da ascendência biológica, sem que seja necessário decidir entre um ou outro vínculo quando o melhor interesse do descendente for o reconhecimento jurídico de ambos." ${ }^{40}$

Por fim, cabe ressaltar que um reflexo direto do exercício de uma paternidade irresponsável seria a denominada alienação parental, atualmente regulamentada pela Lei 12.318/10, caracterizada pela influência psicológica perpetrada por um dos genitores, avós ou quem detenha autoridade do menor no sentido de repudiar ou causar prejuízos ao vínculo existente entre este e o outro genitor. $^{41}$

Conforme exemplificado por Cristiano Chaves e Nelson Rosenvald ${ }^{42}$, são casos típicos de alienação parental a criação de obstáculos à visitação, propagação de notícias desqualificadoras do outro genitor ou omissão de informações importantes sobre a criança ou adolescente.

Tal situação deve ficar efetivamente comprovada com elementos probatórios consistentes para que não sejam cometidos equívocos diante da alegação de uma falsa alienação parental, demandando um acompanhamento psicológico do menor e a adoção das medidas necessárias à garantia de seus direitos.

\subsection{PRINCÍPIO DA IGUALDADE DE FILIAÇÃO}

O princípio da igualdade de filiação vem positivado no artigo $227, \S 6^{\circ}$ da Constituição Federal $^{43}$ e artigo 1.596 do $\mathrm{CC} / 02$, impedindo que se faça

\footnotetext{
${ }^{40}$ Supremo Tribunal Federal, Recurso Extraordinário n ${ }^{\circ}$ 898.060/SC, Rel. Min. Luiz Fux, Brasília, 21 set. 2016. Íntegra do voto do relator. p. 4. Disponível em: < http://www.stf.jus.br/arquivo/cms/noticiaNoticiaStf/anexo/RE898060.pdf>. Acesso em 05 set. 2017.

${ }^{41}$ FARIAS, Cristiano Chaves de; ROSENVALD, Nelson. Op. Cit., p. 105.

${ }^{42}$ Ibid. p. 105.

${ }^{43}$ Art. 227. É dever da família, da sociedade e do Estado assegurar à criança, ao adolescente e ao jovem, com absoluta prioridade, o direito à vida, à saúde, à alimentação, à educação, ao lazer, à profissionalização, à cultura, à dignidade, ao respeito, à liberdade e à convivência familiar e comunitária, além de colocá-los a salvo de toda forma de negligência, discriminação, exploração, violência, crueldade e opressão.

$\S 6^{\circ}$ Os filhos, havidos ou não da relação do casamento, ou por adoção, terão os mesmos direitos e qualificações, proibidas quaisquer designações discriminatórias relativas à filiação.
} 
qualquer discriminação ou hierarquização entre as espécies de filiação, seja de origem biológica ou não.

Trata-se de uma conquista resultante da mudança da concepção familiar (quando a família passa a ser instrumento de realização pessoal dos seus integrantes e não mais o inverso) e do reconhecimento jurídico de uma pluralidade de entidades familiares. ${ }^{44}$

Sendo assim, não mais encontra espaço na sociedade atual a diferenciação entre filhos legítimos ou ilegítimos (seja naturais, incestuosos ou adulterinos), biológicos ou adotivos, devendo todos serem considerados legitimamente iguais para todos os efeitos legais.

Segundo Caio Mário ${ }^{45}$, o artigo 1.593 do Código Civil inclusive admite a possibilidade de filiação socioafetiva quando afirma que o parentesco pode ser natural ou civil, conforme resulte da consanguinidade ou "outra origem".

Conforme destacado por Cristiano Chaves e Nelson Rosenvald ${ }^{46}$ o princípio da igualdade entre os filhos nada mais é do que medida concretizadora da dignidade da pessoa humana, preceito este fundamental na interpretação das relações familiares, elevado a valor nuclear da ordem constitucional, como visto anteriormente.

Além disso, outro não poderia ser o desfecho diante do princípio do melhor interesse da criança e adolescente, sob pena de absoluta incompatibilidade.

Ressalve-se, entretanto, que apesar da proibição de designações discriminatórias relativas à filiação, idealizada pela Constituição Federal, ainda assim permaneceram na lei dispositivos que perpetuam certa distinção, como é

\footnotetext{
${ }^{44}$ PEREIRA, Caio Mário da Silva. Op. Cit., p. 63.

${ }^{45}$ Ibid. p. 64.

${ }^{46}$ FARIAS, Cristiano Chaves de; ROSENVALD, Nelson. Op. Cit., p. 103.
} 
o caso das presunções de paternidade, previstas no artigo 1.597 do Código Civil, onde apenas são alcançados os filhos oriundos de relações matrimoniais, não gozando do mesmo benefício conferido legalmente os filhos extraconjugais, como se verá mais adiante.

De todo modo, o reconhecimento da igualdade de filiação pela Constituição Federal foi um grande avanço social, pois como bem assevera Rolf Madaleno ${ }^{47}$

“(...) a subsistência desse viés diferenciando os filhos do casamento em contraste com a prole extramatrimonial, em nada se equipara ao estigmatizante contexto das filiações legítimas e ilegítimas vigentes até a edição da Constituição Federal de 1988."

\subsection{PRINCÍPIO DO PLURALISMO FAMILIAR}

Com a Constituição Federal de 1988 houve uma ampliação significativa das entidades familiares, o que anteriormente não ocorria, uma vez que apenas o matrimônio era reconhecido como arranjo familiar.

Atualmente, pelo princípio do pluralismo familiar, é reconhecida como família legítima qualquer união que tenha por base o afeto, com comprometimento recíproco de seus integrantes e ligação pessoal e patrimonial. $^{48}$

Conforme destaca Paulo Lôbo $^{49}$, tal princípio retira seu fundamento de outros dois princípios gerais também aplicáveis ao Direito de Família, que seriam a igualdade e a liberdade familiar, uma vez que se reconhece às pessoas o direito de constituir livremente entidades familiares, todas dignas de tratamento isonômico.

Sendo assim, conforme exposto anteriormente, a Constituição foi meramente exemplificativa na enumeração de entidades familiares, merecendo

\footnotetext{
${ }^{47}$ MADALENO, Rolf. Op. Cit., p. 470.

${ }^{48}$ DIAS, Maria Berenice. Op. Cit., p. 49.

${ }^{49}$ LÔBO, Paulo. Op. Cit., p. 53.
} 
igual proteção todas as uniões baseadas na afetividade em prol do melhor interesse das pessoas humanas que as integram. ${ }^{50}$

Isso porque, conforme destacado no julgamento do Recurso Extraordinário $\mathrm{n}^{\circ}$ 898.060/SC, não podem restar ao desabrigo os arranjos familiares que, embora omitidos, ensejam tutela jurídica concomitante, visando a garantia da mais completa e adequada proteção aos direitos dos sujeitos envolvidos.

\subsection{PRINCÍPIO DA PROTEÇÃO INTEGRAL E DO MELHOR INTERESSE DA CRIANÇA E DO ADOLESCENTE}

O princípio do melhor interesse da criança encontra fundamento de validade no artigo 227 da Constituição Federal, bem como na Convenção Internacional dos Direitos da Criança, ambos priorizando os interesses das crianças e adolescentes, como sujeitos de direitos, e não mais meros objetos de decisão dos interesses parentais, como prevalecia antigamente.

Atualmente, tal princípio garante a primazia dos interesses de crianças e adolescentes, como pessoas em desenvolvimento e dotadas de dignidade, o que deve ser observado pelo Estado, pela sociedade como um todo e dentro das relações familiares, tanto na elaboração, quanto na aplicação de seus direitos. ${ }^{51}$

Assim, segundo Rolf Madaleno ${ }^{52}$

“ (...) o legislador constituinte conferiu prioridade aos direitos da criança e do adolescente, ressaltando os seus direitos em primeira linha de interesse, por se tratar de pessoas indefesas e em importante fase de crescimento e de desenvolvimento de sua personalidade."

Daí ter sido consagrado constitucionalmente o princípio que visa assegurar às crianças e adolescentes, com prioridade absoluta, os direitos fundamentais à vida, saúde, alimentação, lazer, educação, profissionalização,

\footnotetext{
${ }^{50}$ Ibid. p. 77.

${ }^{51}$ Ibid. p. 69.

${ }^{52}$ MADALENO, Rolf. Op. Cit., p. 97.
} 
cultura, dignidade, respeito, liberdade e convivência familiar e comunitária, colocando-os a salvo de toda forma de negligência, discriminação, exploração, violência, crueldade e opressão.

Ressalte-se que o princípio do melhor interesse legitima a possibilidade de concomitância da filiação biológica e socioafetiva, tendo sido utilizado de fundamento para a decisão firmada no Recurso Extraordinário n ${ }^{\circ}$ 898.060/SC, quando se afirmou que “(...), nos tempos atuais, descabe pretender decidir entre a filiação afetiva e a biológica quando o melhor interesse do descendente é o reconhecimento jurídico de ambos os vínculos."

\subsection{PRINCÍPIO DA AFETIVIDADE}

O princípio da afetividade é essencial para a compreensão da multiparentalidade, tendo o Supremo Tribunal Federal expressamente aceitado o seu reconhecimento jurídico, através do julgamento da Repercussão Geral 622 (RE 898.060/SC), que será oportunamente analisada.

Trata-se de princípio implícito que fundamenta a igualdade de filiação biológica e não biológica, o respeito a seus direitos fundamentais e a solidariedade recíproca, além de ser o elo que caracteriza as uniões familiares atuais. $^{54}$

Segundo a doutrina de Caio Mário ${ }^{55}$, a afetividade pode ser considerada um princípio jurídico a partir de uma interpretação sistemática da Constituição Federal.

\footnotetext{
${ }^{53}$ Supremo Tribunal Federal, Recurso Extraordinário n ${ }^{\circ}$ 898.060/SC, Rel. Min. Luiz Fux. Brasília, 21 set. 2016. Íntegra do voto do relator. p. 17. Disponível em: < http://www.stf.jus.br/arquivo/cms/noticiaNoticiaStf/anexo/RE898060.pdf>. Acesso em 05 set. 2017.

${ }^{54}$ LÔBO, Paulo. Op. Cit., p. 66.

${ }^{55}$ PEREIRA, Caio Mário da Silva. Op. Cit., p. 65-66.
} 
Nesse mesmo sentido posiciona-se Maria Berenice Dias ${ }^{56}$, ao afirmar que o princípio da afetividade seria o "princípio norteador do direito das famílias".

A doutrina de Cristiano Farias e Nelson Rosenvald ${ }^{57}$, diferentemente dos autores supramencionados, não chega a enumerar a afetividade como um princípio jurídico, pois sustenta que o afeto seria um elemento estrutural das famílias e não um princípio dotado de força normativa, caso contrário se tornaria algo exigível. Assim, segundo os autores, o afeto como elemento intrínseco das famílias permitiria que decisões e providências sejam nele baseadas, mas que não seja dotado de exigibilidade.

Também partilha de tal entendimento Paulo Lôbo ${ }^{58}$, porém com a ressalva de reconhecer a afetividade como princípio jurídico, diferenciando o que seria o afeto e o que seria a afetividade, afirmando que não seria o afeto, enquanto fato social, que poderia ser juridicamente obrigado, mas sim "as condutas que o direito impõe tomando-o como referência."

Por fim, quanto à afetividade, Farias e Rosenvald ${ }^{59}$ destacam que somente é possível invocá-la objetivando determinar o vínculo parental, jamais se podendo fundamentar em uma "desafetividade" para negar um estado de filiação, o que apenas poderia ser feito com base nos demais critérios de filiação, os quais nos aprofundaremos no próximo capítulo.

\footnotetext{
${ }^{56}$ DIAS, Maria Berenice. Op. Cit., p. 54.

${ }^{57}$ FARIAS, Cristiano Chaves de; ROSENVALD, Nelson. Op. Cit., p. 33.

${ }^{58}$ LÔBO, Paulo. Op. Cit., p. 25.

${ }^{59}$ FARIAS, Cristiano Chaves de; ROSENVALD, Nelson. Op. Cit., p. 595.
} 


\section{FILIAÇÃO}

Pelo presente capítulo pretende-se abranger algumas noções a respeito da filiação, destacando o que se demonstra pertinente ao presente estudo, bem como pormenorizando os três critérios utilizados para identificá-la, além da denominada posse de estado de filho, por se revelar oportuna ao tema.

Antes, porém, convém ressaltar que não se tem a pretensão de esgotar todos os aspectos que envolvem a matéria filiatória, mas tão somente mencionar suas principais características necessárias à compreensão da multiparentalidade.

\subsection{NOÇÕES GERAIS E TENTATIVA CONCEITUAL}

Como vimos anteriormente, a Constituição Federal de 1988 trouxe a igualdade substancial entre os filhos estampada no artigo $227, \S 6^{\circ}$ e repetida no artigo 1.596 do $\mathrm{CC} / 02$, eliminando-se qualquer tratamento discriminatório que a eles era conferido, seja em razão de sua origem ou situação jurídica de seus pais. ${ }^{60}$

Sendo assim, como bem destacam Farias e Rosenvald ${ }^{61}$, promoveu-se uma "total desvinculação, um desatrelamento completo, entre a filiação e o tipo de relação familiar mantida pelos genitores (ou mesmo não mantida por eles)."

Ocorre que, contraditoriamente, o Código Civil de 2002 manteve as presunções de paternidade apenas para os filhos de pessoas casadas, ignorando a pluralidade de entidades familiares consagrada pela Constituição atual. ${ }^{62}$

De todo modo, a nova ordem jurídica, abandonando a feição meramente patrimonialista de família, passou priorizar a dignidade da pessoa humana e o

\footnotetext{
${ }^{60}$ Ibid. p. 539.

${ }^{61}$ Ibid. p. 540.

62 Ibid. p. 540.
} 
interesse das crianças e adolescentes como sujeitos de direito, bem como proibiu as referidas designações discriminatórias quanto à filiação. ${ }^{63}$

Nesse sentido sustentam Farias e Rosenvald ${ }^{64}$ que

"Todo e qualquer tipo de relação paterno-filial merece proteção especial no cenário descortinado pela Constituição da República, o que, em última análise, corresponde à tutela avançada da pessoa humana e de sua intangível dignidade"

Como bem destaca Maria Berenice Dias ${ }^{65}$, dentro desse contexto, a origem genética deixou de ser determinante para a definição do vínculo de filiação. Logo, essa nova mentalidade que passou a nortear o Direito de Família refletiu também no reconhecimento de novas formas de filiação, como é o caso da filiação socioafetiva, de maneira a melhor retratar a realidade atual.

Fala-se que ocorreu uma espécie de "desbiologização da paternidade", deixando o critério biológico de ocupar posição central e predominante nas relações parentais para ceder lugar à afetividade, podendo prevalecer o critério socioafetivo frente ao biológico, quando assim determinar o melhor interesse do filho. ${ }^{66}$

Isso porque, conforme precisa lição de Farias e Rosenvald ${ }^{67}$, não é necessária a geração biológica do filho para que se vislumbre a filiação, uma vez que "seu elemento essencial está na vivência e crescimento cotidiano, nessa mencionada busca pela realização e desenvolvimento pessoal (aquilo que se chama, comumente, de felicidade)."

\footnotetext{
${ }^{63}$ DIAS, Maria Berenice. Op. Cit., p. 389.

${ }^{64}$ FARIAS, Cristiano Chaves de; ROSENVALD, Nelson. Op. Cit., p. 541.

${ }^{65}$ DIAS, Maria Berenice. Op. Cit., p. 389.

${ }^{66}$ PENNA, Saulo Versiani; ARAUJO, Deborah Nayara dos Reis. Famílias brasileiras reconstituidas e a multiparentalidade: adequação do direito à realidade socioafetiva. Revista IBDFAM: Famílias e Sucessões, n. 21, mai.-jun. 2017. Belo Horizonte: IBDFAM, 2017. p. 31.

${ }^{67}$ FARIAS, Cristiano Chaves de; ROSENVALD, Nelson. Op. Cit., p. 543.
} 
Assim, ainda segundo Farias e Rosenvald, a filiação pode ser conceituada como uma relação jurídica multifacetária ${ }^{68}$, estabelecida em primeiro grau, em linha reta, "entre uma pessoa e aqueles que a geraram ou que a acolheram e criaram, com base no afeto e na solidariedade, almejando o desenvolvimento da personalidade e a realização pessoal." ${ }^{, 69}$

Atribui-se à filiação um sentido plural, caraterizado por um "mosaico de possibilidades", uma vez que atualmente enxergam-se múltiplos meios de se estabelecer uma relação paterno-filial. ${ }^{70}$

Portanto, serão destacados a seguir três diferentes critérios utilizados para o estabelecimento do vínculo parental, quais sejam: (3.2) critério jurídico ou legal, que estabelece a paternidade por meio de presunções; (3.3) critério biológico, possível após os avanços científicos que permitiram a realização do exame de DNA; (3.4) critério socioafetivo, baseado nos princípios do melhor interesse da criança e na dignidade da pessoa humana. ${ }^{71}$

Cumpre ressaltar, desde já, que não há que se falar em prevalência ou hierarquia apriorística entre os supramencionados critérios, sendo que apenas casuisticamente vai poder ser verificada alguma preferência entre eles.

\subsection{CRITÉRIO JURÍDICO (OU LEGAL)}

O critério jurídico ou ainda denominado critério da presunção legal, como o próprio nome define, está baseado em presunções de paternidade de filhos nascidos de uma relação familiar casamentária.

Sendo assim, conforme destacam Farias e Rosenvald ${ }^{72}$, não é difícil concluir que tal critério filiatório tem como figura central e principal a família

\footnotetext{
${ }^{68}$ Por envolver, como destacam os autores, três diferentes perspectivas: do filho (filiação propriamente dita), do pai (paternidade) e da mãe (maternidade).

${ }^{69}$ FARIAS, Cristiano Chaves de; ROSENVALD, Nelson. Op. Cit., p. 543.

${ }^{70}$ Ibid. p. 563.

${ }^{71}$ DIAS, Maria Berenice. Op. Cit., p. 390.

${ }^{72}$ FARIAS, Cristiano Chaves de; ROSENVALD, Nelson. Op. Cit., p. 565.
} 
matrimonializada, inserido em um contexto em que se visava essencialmente a preservação do casamento, ignorando os relacionamentos afetivos eventualmente existentes. $^{73}$

Isso fazia sentido, como já devidamente explicado, dentro da lógica vigente anteriormente, mas dentro da atual percepção do Direito de Família, esperava-se o abandono das referidas presunções, o que, entretanto, não ocorreu com o advento do Código Civil de 2002.

Assim, o Código Civil regulamenta o critério legal, através do seu artigo $1.597^{74}$, "pelo qual a filiação decorre de uma presunção prevista em lei”, que não vai levar em consideração a verdade biológica, utilizando-se da presunção para reconhecer como mãe aquela indicada pelo parto e o pai o marido dela. ${ }^{75}$

O critério jurídico ou legal é identificado, então, por uma expressão latina: pater is est quem nuptiae demonstrant (pai é aquele que as núpcias demonstram $)^{76}$, que vem acompanhada de outra expressão: mater semper certa est (a mãe é sempre certa) ${ }^{77}$.

Conforme destacado anteriormente, a lei estabeleceu tais presunções de paternidade apenas quanto ao casamento, ignorando as demais entidades familiares, como a união estável.

\footnotetext{
${ }^{73}$ DIAS, Maria Berenice. Op. Cit., p. 391.

${ }^{74}$ Art. 1.597. Presumem-se concebidos na constância do casamento os filhos:

I - nascidos cento e oitenta dias, pelo menos, depois de estabelecida a convivência conjugal;

II - nascidos nos trezentos dias subsequentes à dissolução da sociedade conjugal, por morte, separação judicial, nulidade e anulação do casamento;

III - havidos por fecundação artificial homóloga, mesmo que falecido o marido;

IV - havidos, a qualquer tempo, quando se tratar de embriões excedentários, decorrentes de concepção artificial homóloga;

V - havidos por inseminação artificial heteróloga, desde que tenha prévia autorização do marido.

${ }^{75}$ FARIAS, Cristiano Chaves de; ROSENVALD, Nelson. Op. Cit., p. 565.

${ }^{76}$ DIAS, Maria Berenice. Op. Cit., p. 393.

${ }^{77}$ FARIAS, Cristiano Chaves de; ROSENVALD, Nelson. Op. Cit., p. 565.
} 
Assim, defende $\operatorname{Dias}^{78}$ que embora o referido artigo faça menção somente à "constância do casamento", tais presunções também seriam aplicáveis à união estável.

A esse respeito manifesta-se também Paulo Lôbo $^{79}$, defendendo a aplicação da presunção de concepção do filho a qualquer entidade familiar, devendo a referência legal, expressa apenas à convivência conjugal, ser lida de forma a abranger também a convivência em união estável.

Diversas são as hipóteses e outras críticas levantadas quanto ao critério das presunções legais, mas não iremos aqui nos alongar esmiuçando-as, uma vez que se objetivava apenas apresentar uma noção geral do que representa tal critério para a determinação da filiação.

\subsection{CRITÉRIO BIOLÓGICO}

Dentro do contexto anteriormente destacado da Constituição de 1988, que vedou qualquer tratamento discriminatório entre os filhos, atrelado aos avanços das pesquisas científicas que permitiram a determinação genética da filiação, o critério legal ou jurídico sofreu significante impacto, deixando de assumir posição protagonista na definição filiatória para dar lugar ao denominado critério biológico. $^{80}$

Assim, através do exame de DNA, possibilitou-se a descoberta da denominada verdade genética ou real, que, com precisão científica, consegue identificar a origem biológica, diferentemente da verdade jurídica, definida basicamente por meio de presunções. ${ }^{81}$

\footnotetext{
${ }^{78}$ DIAS, Maria Berenice. Op. Cit., p. 393.

${ }^{79}$ LÔBO, Paulo. Op. Cit., p. 207.

${ }^{80}$ FARIAS, Cristiano Chaves de; ROSENVALD, Nelson. Op. Cit., p. 587.

${ }^{81}$ DIAS, Maria Berenice. Op. Cit., p. 391.
} 
Trata-se da filiação decorrente do vínculo de consanguinidade, a que se refere o artigo 1.593 do Código Civil, obtido pela análise genética, sendo até hoje referência quando se fala em filiação e em reconhecimento de filho. ${ }^{82}$

A importância assumida pelo critério biológico foi tamanha que a jurisprudência passou a adotar uma presunção relativa da paternidade que se pretendia provar, na hipótese de recusa injustificada em se submeter ao exame de DNA. É o que dispõe a súmula 301 do STJ: "Em ação investigatória, a recusa do suposto pai a submeter-se ao exame de DNA induz presunção juris tantum de paternidade." ${ }^{\Perp 3}$

Entretanto, como bem asseveram Farias e Rosenvald, a grande valia do critério biológico não pode significar sua divinização, uma vez que "outros fatores são, igualmente, relevantes na determinação da condição de filho" ${ }^{84}$, como é o caso do critério socioafetivo que será mais detalhadamente analisado a seguir.

Assim, concluo pelas palavras de Daniela Paiano ${ }^{85}$

“(...) a consanguinidade não é a única fonte de se estabelecer filiação. Além de ser pai biológico, deve-se 'escolher' ser pai e, mais, pai daquele filho. A paternidade passa então a ter a dimensão do afeto inserida em seu conceito e em sua concretude, de modo que uma paternidade biológica pode ao mesmo tempo ser afetiva ou não."

\subsection{CRITÉRIO SOCIOAFETIVO}

A filiação socioafetiva, por sua vez, encontra alicerce no art. $227, \S 6^{\circ}$ da Constituição Federal $^{86}$ e art. 1.593 do Código $\mathrm{Civil}^{87}$, quando este se refere à

\footnotetext{
${ }^{82}$ Ibid. p. 397.

${ }^{83}$ FARIAS, Cristiano Chaves de; ROSENVALD, Nelson. Op. Cit., p. 588-589.

${ }^{84}$ Ibid. p. 589.

${ }^{85}$ PAIANO, Daniela Braga. A Família Atual e as Espécies e Filiação: Da Possibilidade Jurídica da Multiparentalidade. Rio de Janeiro: Lumen Juris, 2017. p. 56.

${ }^{86}$ Art. 227. $\S 6^{\circ}$ Os filhos, havidos ou não da relação do casamento, ou por adoção, terão os mesmos direitos e qualificações, proibidas quaisquer designações discriminatórias relativas à filiação.

${ }^{87}$ Art. 1.593. O parentesco é natural ou civil, conforme resulte de consangüinidade ou outra origem.
} 
"outra origem" além da consanguinidade, de modo a contemplar a socioafetividade, conforme destacam Dias ${ }^{88}$ e Pereira ${ }^{89}$.

Partilhando da mesma interpretação do artigo 1.593, Farias e Rosenvald ${ }^{90}$ destacam ainda que é nesse exato sentido o Enunciado 108 da I Jornada de Direito Civil ("no fato jurídico do nascimento, mencionado no art. 1.603, compreende-se, à luz do disposto no art. 1.593, a filiação consangüínea e também a socioafetiva"), bem como o Enunciado 256 da III Jornada de Direito Civil ("a posse do estado de filho (parentalidade socioafetiva) constitui modalidade de parentesco civil").

É nesse sentido que o Projeto de Lei $n^{\circ}$ 2.285/07, conhecido como Estatuto das Famílias, prevê claramente a socioafetividade como forma de parentesco, ao dispor, em seu artigo 10, que "o parentesco resulta da consanguinidade, da socioafetividade ou da afinidade" (redação esta semelhante ao que dispõe o Projeto de Lei ${ }^{\circ}$ 470/13, Estatuto das Famílias de iniciativa do IBDFAM, em seu artigo $9^{\circ}$ ).

Daniela Paiano ${ }^{91}$ chega a defender a inserção de um $\S 1^{\circ}$ no referido art. 1.593 do Código Civil, para que se faça alusão expressa à multiparentalidade, sustentando que conste: "o parentesco poderá ser natural e civil quando resultante da multiparentalidade", de maneira a se adequar aos novos arranjos familiares atuais.

Rolf Madaleno ${ }^{92}$ menciona ainda três outras passagens em que o Código Civil faria menção à filiação socioafetiva:

\footnotetext{
${ }^{88}$ DIAS, Maria Berenice. Op. Cit., p. 406.

${ }^{89}$ PEREIRA, Caio Mário da Silva. Op. Cit., p. 64.

${ }^{90}$ FARIAS, Cristiano Chaves de; ROSENVALD, Nelson. Op. Cit., p. 593.

${ }^{91}$ PAIANO, Daniela Braga. Op. Cit., p. 46.

${ }^{92}$ MADALENO, Rolf. Op. Cit., p. 475.
} 
(1) art. 1.597, V, ao reconhecer a filiação conjugal havida por inseminação artificial heteróloga, quando então o marido será considerado o pai e não o terceiro doador do material genético; (2) art. 1.603, quando este estabelece o termo de nascimento como prova de filiação, ninguém podendo vindicar estado contrário ao que resulta do registro de nascimento, salvo prova de erro ou falsidade do registro, "e nesse sentido a jurisprudência vem construindo a base jurídica da filiação socioafetiva"; (3) art. 1.605, II, quando estabelece que na falta ou defeito do termo de nascimento pode a filiação ser provada pela existência de veementes presunções resultantes de fatos já certos, em referência à denominada posse de estado de filho, que será posteriormente analisada.

Destaca-se que o critério socioafetivo é norteado não pelo nascimento, mas decorrente de um "conjunto de atos de afeição e solidariedade", através de uma "convivência cotidiana, de uma construção diária, não se explicando por laços genéticos, mas pelo tratamento estabelecido entre pessoas que ocupam reciprocamente o papel de pai e filho, respectivamente." ${ }^{93}$

Ou seja, verifica-se a filiação socioafetiva, num ato de vontade, manifestado pelo exercício fático da função paterna, o que possibilita, portanto, a cisão entre os conceitos de genitor e pai.

O ideal, entretanto, seria que houvesse uma coincidência entre a filiação biológica e a socioafetiva, conforme sustentam Farias e Rosenvald. ${ }^{94}$ E, nesse sentido, Paulo Lôbo ${ }^{95}$ defende ser a paternidade biológica espécie do fenômeno socioafetivo, que abrangeria a filiação biológica e a não biológica.

\footnotetext{
${ }^{93}$ FARIAS, Cristiano Chaves de; ROSENVALD, Nelson. Op. Cit., p. 593.

${ }^{94}$ Ibid. p. 590.

${ }^{95}$ LÔBO, Paulo. Op. Cit., p. 198.
} 
Cumpre ressaltar que é reconhecida jurisprudencialmente tanto a paternidade quanto a maternidade socioafetiva, ambas espécies da denominada parentalidade socioafetiva.

Especificamente quanto à parentalidade socioafetiva, Cassettari ${ }^{96}$ a define como o "vínculo de parentesco civil entre pessoas que não possuem entre si um vínculo biológico, mas que vivem como se parentes fossem, em decorrência do forte vínculo existente entre elas."

Ou seja, imprescindível para a configuração da parentalidade socioafetiva que haja a presença de laços de afetividade recíprocos, bem como uma convivência familiar duradoura e voluntária, sendo que, após seu reconhecimento, se tornaria irrevogável, irretratável e indisponível ${ }^{97}$, conforme depreende-se do seguinte julgado:

\begin{abstract}
“Apelação. Negatória De Paternidade. Anulação De Reconhecimento De Filho. Vício De Vontade Não Comprovado. Irrevogabilidade. Paternidade Socioafetiva Configurada. 1. O reconhecimento voluntário de paternidade é irrevogável e irretratável, e não cede diante da inexistência de vínculo biológico, pois a revelação da origem genética, por si só, não basta para desconstituir o vínculo voluntariamente assumido. 2. A relação jurídica de filiação se construiu também a partir de laços afetivos e de solidariedade entre pessoas geneticamente estranhas que estabelecem vínculos que em tudo se equiparam àqueles existentes entre pais e filhos ligados por laços de sangue. Inteligência do art. 1.593 do Código Civil. 3. O reconhecimento voluntário de paternidade, com ou sem dúvida por parte do reconhecente, é irrevogável e irretratável (arts. 1609 e 1610 do Código Civil), somente podendo ser desconstituído mediante prova de que se deu mediante erro, dolo ou coação, vícios aptos a nulificar os atos jurídicos em geral. Considerando que a instrução não trouxe qualquer elemento que corroborasse a tese de erro, ou outro vício qualquer de vontade, prevalece a irrevogabilidade do reconhecimento voluntário de paternidade, que, no caso, corresponde a uma "adoção à brasileira". Precedentes. NEGARAM PROVIMENTO. UNÂNIME." 98
\end{abstract}

Ressalte-se, por outro lado, que a análise da presença da afetividade deve se dar quanto ao período de convivência, não interessando se o afeto não está

\footnotetext{
${ }^{96}$ CASSETTARI, Christiano. Multiparentalidade e parentalidade socioafetiva: efeitos jurídicos. $3^{\text {a }}$ ed.. São Paulo: Atlas, 2017. p. 17.

${ }^{97}$ Ibid. p. 36.

${ }^{98}$ Tribunal de Justiça do Rio Grande do Sul, Apelação Cível n ${ }^{\circ}$ 70040743338/RS, Rel. Luiz Felipe Brasil Santos, Porto Alegre, 12 mai. 2011.
} 
mais presente no instante em que se discute a filiação em juízo, caso anteriormente ele fosse o liame que entrelaçou aquelas pessoas. ${ }^{99}$

Segundo Cassettari ${ }^{100}$, a parentalidade socioafetiva pode ter origem em diferentes situações como através da denominada posse de estado de filho, adoção de fato, adoção à brasileira, em casos de filhos havidos fora do casamento ou por reprodução assistida heteróloga, ou ainda em decorrência da relação de padrastio e madrastio.

Como não se pretende pelo presente trabalho esgotar todas as nuances abarcadas pela socioafetividade, mas tão somente destacar seus principais aspectos fundamentais ao estudo que se propôs propriamente da multiparentalidade desenvolvida no âmbito de famílias recompostas, não serão tratadas todas as referidas hipóteses que podem dar ensejo à parentalidade socioafetiva.

Portanto, iremos restringir o presente estudo apenas à parentalidade socioafetiva que nasce da posse de estado de filho e aquela em decorrência da chamada relação de padrastio e madrastio, vista no bojo de famílias reconstituídas, onde a multiplicidade relacional e afetiva dá ensejo à pluriparentalidade.

Conforme destaca Dias, "a filiação socioafetiva assenta-se no reconhecimento da posse de estado de filho: a crença da condição de filho fundada em laços de afeto" ${ }^{\text {101 }}$, razão pela qual a analisaremos mais detidamente a seguir.

\footnotetext{
${ }^{99}$ FARIAS, Cristiano Chaves de; ROSENVALD, Nelson. Op. Cit., p. 594.

${ }^{100}$ CASSETTARI, Christiano. Op. Cit., p. 271.

${ }^{101}$ DIAS, Maria Berenice. Op. Cit., p. 405.
} 


\subsubsection{POSSE DE ESTADO DE FILHO}

A posse de estado de filho, como bem destaca Paulo Lôbo ${ }^{102}$, se refere à situação fática na qual uma pessoa desfruta do status de filho em relação a outra, independentemente dessa situação corresponder à realidade legal.

Segundo Rolf Madaleno ${ }^{103}$

"A noção de posse do estado de filho vem recebendo abrigo nas reformas do direito comparado, o qual não estabelece os vínculos parentais com o nascimento, mas sim na vontade de ser genitor, e esse desejo é sedimentado no terreno da afetividade, e põe em xeque tanto a verdade jurídica como a certeza científica no estabelecimento da filiação."

Apesar do ordenamento jurídico brasileiro não contemplar expressamente essa noção, Cassettari ${ }^{104}$ destaca ser ela um dos fatos geradores da parentalidade socioafetiva, em razão do que determina a redação do art. 1.605, II, $\mathrm{CC} / 02{ }^{105}$

Ainda, por meio da análise do Enunciado $\mathrm{n}^{\circ} 519$ do Conselho da Justiça Federal ${ }^{106}$, pode-se concluir que é fundamental a constituição da posse de estado de filho para que haja o reconhecimento da parentalidade socioafetiva,

Cumpre também destacar o Enunciado n ${ }^{\circ} 7$ do IBDFAM, que estabelece que "a posse de estado de filho pode constituir a paternidade e maternidade."

Nos dizeres de Penna e Araujo ${ }^{107}$, a posse de estado de filho dá ensejo à filiação socioafetiva e é verificável pelo

\footnotetext{
${ }^{102}$ LÔBO, Paulo. Op. Cit., p. 215.

${ }^{103}$ MADALENO, Rolf. Op. Cit., p. 472.

${ }^{104}$ CASSETTARI, Christiano. Op. Cit. p. 37.

${ }^{105}$ Art. 1.605. Na falta, ou defeito, do termo de nascimento, poderá provar-se a filiação por qualquer modo admissível em direito: II - quando existirem veementes presunções resultantes de fatos já certos.

106 Enunciado 519 CJF: "O reconhecimento judicial do vínculo de parentesco em virtude de socioafetividade deve ocorrer a partir da relação entre pai(s) e filho(s), com base na posse do estado de filho, para que produza efeitos pessoais e patrimoniais."

${ }^{107}$ Penna, Saulo Versiani;Araujo, Deborah Nayara dos Reis. Op. Cit., p. 31.
} 
“(...) tratamento a alguém de forma pública como se filho seu fosse, expresso pelo cuidado, dedicação, atenção e assistência, mercê da ausência de vínculo biológico, mas que, por voluntariedade, mostra-se como houvesse (...)"

São elencados doutrinariamente três elementos para a configuração da posse de estado de filiação, quais sejam: tratamento (tractatus), fama (reputatio) e nome (nominatio).

O tratamento resta configurado quando o filho socioafetivo é efetivamente tratado como filho, tanto dentro do âmbito familiar como fora dele, dando a ele criação, educação e meios de subsistência em geral. Já a fama corresponde à visão da opinião pública, ou seja, se perante a sociedade há um reconhecimento público de seu status como filho dentro daquela entidade familiar. Por fim, o requisito de nome representaria a utilização do nome de família daquele que lhe atribui a paternidade, mas, segundo destacam Farias e Rosenvald, tal requisito não seria decisivo, "possuindo menor ou nenhuma importância para a determinação da posse do estado de filho."108

Cassettari $^{109}$ ressalta ainda que tais requisitos não são exclusivos à configuração da parentalidade socioafetiva, devendo também ser observados na parentalidade biológica, uma vez que os pais biológicos devem tratar seus filhos como se também fossem socioafetivos, conjugando os três citados elementos.

Ainda conforme as lições de Cassettari ${ }^{110}$

“(...)podemos afirmar que a parentalidade que se forma pela posse do estado de filho é a aplicação da denominada teoria da aparência sobre as relações paterno-filiais, estabelecendo uma situação fática que merece tratamento jurídico.”

Ocorre que, atualmente, a posse de estado de filho é vista apenas como um meio comprobatório, um meio de prova subsidiário do vínculo afetivo

\footnotetext{
${ }^{108}$ FARIAS, Cristiano Chaves de; ROSENVALD, Nelson. Op. Cit., p. 548.

${ }^{109}$ CASSETTARI, Christiano. Op. Cit. p. 39.

${ }^{110}$ Ibid. p. 42.
} 
existente entre pais e filhos de criação, sendo incapaz de, por si só, constituir o vínculo socioafetivo propriamente. ${ }^{11}$

Assim, compreende-se que é o exercício fático da autoridade parental, externado por condutas objetivas como criar, educar e assistir a prole, que será capaz de gerar o vínculo jurídico da parentalidade. Ou seja, não é a paternidade ou maternidade que ocasiona a titularidade da autoridade parental e sim o inverso, uma vez que é o exercício concreto desses deveres inerentes ao poder familiar que produzirão o vínculo parental. ${ }^{112}$

Reiteradas são as decisões em que se reconhece a pluriparentalidade com fundamento na verificação da posse de estado de filho, sem haver a exclusão do vínculo com o genitor, mas apenas a reconhecendo e, consequentemente, acrescendo uma nova filiação.

Portanto, feitas as considerações necessárias, prosseguiremos com um estudo mais aprofundado propriamente do fenômeno da multiparentalidade, devido à relevância que demonstra atualmente sua discussão no âmbito do Direito de Família.

111 TEIXEIRA, Ana Carolina Brochado; RODRIGUES, Renata de Lima. A multiparentalidade como nova estrutura de parentesco na contemporaneidade. Revista Brasileira de Direito Civil, volume 4, abr.-jun. 2015. p. 17.

${ }^{112}$ Ibid. p. 20. 


\section{MULTIPARENTALIDADE}

A multiparentalidade está presente quando identificada uma multiplicidade de vínculos de filiação, onde todos os pais assumem os encargos decorrentes do poder familiar, bem como o filho que desfruta de direitos e deveres em relação a todos. ${ }^{113}$

Daniela Paiano ${ }^{114}$, ao conceituar o fenômeno da multiparentalidade assim o define:

“(...) a multiparentalidade é um fenômeno jurisprudencial e doutrinário, advindo de uma interpretação conforme, integrativa e expansiva, que permite o reconhecimento de mais de um pai ou mãe a uma mesma pessoa, de modo que conste em seu registro de nascimento as consequências desse reconhecimento - alteração de nome, inclusão de outro pai ou mãe, inclusão de outros avós."

Schreiber e Lustosa ${ }^{115}$ ressaltam ainda que a multiparentalidade pode ser conceituada em uma acepção ampla (mais de um vínculo parental paterno ou mais de um vínculo parental materno, abarcando, portanto, casos de simples biparentalidade homoafetiva) ou em uma acepção estrita (três ou mais laços parentais, não abrangendo a mera dupla paternidade/maternidade).

Divergindo dos autores supramencionados, Cassettari ${ }^{116}$ defende que a multiparentalidade não se confunde com a biparentalidade, formada por apenas duas pessoas, seja de mesmo sexo (bipaternidade ou bimaternidade) ou de sexo oposto (biparentalidade propriamente).

Conforme destaca Christiano Cassettari ${ }^{117}$, é caracterizada pela concomitância de três ou mais pessoas no registro de nascimento de uma pessoa natural, podendo ser classificada ainda em multiparentalidade materna

\footnotetext{
${ }^{113}$ DIAS, Maria Berenice. Op. Cit., p. 409.

${ }^{114}$ PAIANO, Daniela Braga. Op. Cit., p. 155.

115 SCHREIBER, Anderson; LUSTOSA, Paulo Franco. Efeitos Jurídicos da multiparentalidade. Revista Pensar. Fortaleza, v. 21, n. 3, set.-dez. 2016. p. 851.

${ }^{116}$ CASSETTARI, Christiano. Op. Cit., 172.

${ }^{117}$ Ibid. p. 172.
} 
ou paterna, a depender da predominância feminina ou masculina, respectivamente.

O instituto que é objeto de estudo do presente trabalho é, portanto, essa entidade familiar denominada multiparentalidade, em sua acepção restrita, que faticamente se verifica cada vez mais na sociedade atual e paulatinamente vem sendo aceita pela doutrina e jurisprudência por meio de uma interpretação sistemática de alguns princípios constitucionais, conforme destacado no segundo capítulo.

Com a facilitação do divórcio, após o advento da Lei do Divórcio em 1977 e principalmente pós Emenda Constitucional $n^{\circ}$ 66/2010, foram crescendo significativamente os casos de pessoas que se divorciam e casam novamente, levando consigo filhos advindos do relacionamento anterior que, inevitavelmente, passam a ser criados também por eventuais padrastos e/ou madrastas, no contexto dessas denominadas famílias recompostas.

Consequentemente, no seio das famílias reconstituídas podem nascer laços de afetividade e solidariedade com os padrastos e/ou madrastas, que não possuem o condão de excluir o vínculo biológico existente, mas tão somente acrescer um novo elo familiar socioafetivo, consignando a denominada multiparentalidade, em virtude da pluralidade de relações parentais que se constitui nesse novo contexto familiar.

No entanto, a grande questão é que o Direito de Família foi todo construído a partir do paradigma do primeiro casamento, inicialmente como uma união indissolúvel, conforme explicado oportunamente.

Ocorre que a sociedade evoluiu e foram necessários reajustes legais para eliminar os entraves existentes à dissolução conjugal e permitir a ampla liberdade aos indivíduos. 
Eliminados os óbices até então existentes, permanecemos ainda sem uma regulamentação adequada a ser dispendida à realidade das famílias recompostas e da multiparentalidade, apesar de ser crescente sua formação e não existirem impeditivos legais ao seu reconhecimento, além de expressamente ser admitido que ela gera efeitos jurídicos ${ }^{118}$.

Vivemos em uma sociedade caracterizada por arranjos e desarranjos familiares que merecem e devem ser reconhecidos juridicamente como entidades familiares próprias e tutela jurídica autônoma.

É inevitável ao padrasto ou madrasta, inserido no contexto de famílias reconstituídas, acumularem funções inerentes à paternidade ou maternidade em relação àquele filho com quem convive diariamente tratando-o como se biológico fosse.

Portanto, os tópicos a seguir pretendem abordar a multiparentalidade através de uma análise doutrinária e jurisprudencial, destacando-se os avanços que já podem ser verificados, bem como aqueles que ainda se demonstram necessários.

\subsection{ASPECTOS GERAIS}

A multiparentalidade, conforme destacado, é caracterizada pela coexistência de múltiplos parentescos possíveis de averbação em registro de nascimento, oriundo de relações de afeto firmadas no contexto das famílias reconstituídas. ${ }^{119}$

Segundo Penna e Araujo ${ }^{120}$, seu reconhecimento é possível a partir de uma interpretação dos princípios constitucionais da liberdade de desconstituição, da solidariedade familiar, fraternidade e do melhor interesse

\footnotetext{
${ }^{118}$ Enunciado n 09 do IBDFAM: "A multiparentalidade gera efeitos jurídicos."

${ }^{119}$ PENNA, Saulo Versiani; ARAUJO, Deborah Nayara dos Reis. Op. Cit., p. 27.

${ }^{120}$ Ibid. p. 27.
} 
da criança e adolescente, além dos demais princípios destacados no capítulo anterior.

Importante salientar que a multiparentalidade se fundamenta, principalmente, na possibilidade de concomitância entre a filiação socioafetiva e a biológica, superando-se a máxima de que deveria prevalecer uma ou outra, consagrada na jurisprudência, que não mais merece prosperar de maneira absoluta, devendo ser analisada casuisticamente eventual prevalência ou sua coexistência.

Com o reconhecimento da multiparentalidade pode-se dizer que vai haver também uma ampliação dos vínculos de parentesco do filho, alterando sua árvore genealógica ao the conceder novos ascendentes e colaterais (avós, bisavós, irmãos, tios, primos, etc.) ${ }^{121}$, uma vez que manterá o parentesco natural com seus pais biológicos e o parentesco civil pela via socioafetiva ${ }^{122}$, aplicando-se os impedimentos matrimoniais a ambos os parentescos.

Ressalte-se ainda que a multiparentalidade também caminha no respeito ao direito da busca da felicidade. Isso porque a felicidade será o tanto mais ampla com o reconhecimento de tantos vínculos afetivos quanto demonstrados pela existência de afeto, convivência pública e duradoura.

Assim, as próximas questões que abordaremos são, além de seus principais aspectos, os problemas e reflexos que seu reconhecimento geraria. Seria possível o registro concomitante de diversos vínculos? Como seria exercido o poder familiar? Caberia também ao pai ou mãe afetiva exercê-lo? Haveria que se falar em uma superposição de papéis parentais em uma família reconstituída? Os alimentos seriam devidos por todos? Quanto à guarda e

\footnotetext{
${ }^{121}$ CASSETTARI, Christiano. Op. Cit., p. 121.

${ }^{122}$ PAIANO, Daniela Braga. Op. Cit., p. 194.
} 
visitação, como compatibilizar diante de uma multiplicidade filiatória? Essas e outras questões serão tratadas mais detalhadamente a seguir.

\subsection{CONCOMITÂNCIA DA FILIAÇÃO BIOLÓGICA E SOCIOAFETIVA}

Conforme já destacado, a admissão da multiparentalidade pressupõe o reconhecimento da possibilidade de concomitância entre as filiações biológicas e afetivas, ambas em patamar de igualdade, afastando-se do entendimento jurisprudencial predominante até então de prevalência de uma em detrimento de outra e de impossibilidade de sua coexistência.

Tartuce $^{123}$, ao se posicionar favoravelmente ao reconhecimento da multiparentalidade, critica a referida posição jurisprudencial ao afirmar que acabava provocando uma verdadeira "escolha de Sofia, entre o vínculo biológico e o socioafetivo, o que não pode mais prosperar."

Isso porque o reconhecimento da concomitância de vínculos parentais afetivos e biológicos é, além de um direito dos envolvidos, uma obrigação constitucional, em observância aos princípios da dignidade da pessoa humana e da afetividade. ${ }^{124}$

Ainda, destaca-se que em razão do princípio da igualdade de filiação, todos os direitos e deveres aplicáveis à filiação biológica devem também ser observados para a filiação socioafetiva.

A esse respeito posiciona-se Belmiro Pedro Welter ${ }^{125}$ ao tecer comentários a uma decisão do Tribunal de Justiça do Rio Grande do Sul:

\footnotetext{
${ }^{123}$ TARTUCE, Flávio; SIMÃO, José Fernando. Direito Civil: Vol. 5 Direito de Família. $7^{\text {a }}$ ed.. São Paulo: Método, 2012. p. 347.

${ }^{124}$ DIAS, Maria Berenice. Op. Cit., p. 409.

${ }^{125}$ WELTER, Belmiro Pedro. Teoria tridimensional no Direito de Família: reconhecimento de todos os direitos das filiações genética e socioafetiva. Decisão comentada do Tribunal de Justiça do Rio Grande do Sul. p. 25. Disponível em: < http://www.amprs.org.br/arquivos/revista_artigo/arquivo_1246467677.pdf>. Acesso em 16 de out. 2017.
} 
“(...) não é correto afirmar, como o faz a atual doutrina e jurisprudência do mundo ocidental, que "a paternidade socioafetiva se sobrepõe à paternidade biológica", ou que "a paternidade biológica se sobrepõe à paternidade socioafetiva", isso porque ambas as paternidades são iguais, não havendo prevalência de nenhuma delas, exatamente porque fazem parte da condição humana tridimensional, que é genética, afetiva e ontológica."

No entanto, tal entendimento não é pacífico na doutrina, havendo autores como Farias e Rosenvald ${ }^{126}$ que sustentam que o reconhecimento da paternidade socioafetiva implica, necessariamente, no afastamento do vínculo biológico, não podendo este exercer o poder familiar ou contra este requerer alimentos ou invocar direito à herança, por exemplo.

Dessa forma, defendem os autores que a filiação socioafetiva produzirá automaticamente todos os efeitos patrimoniais (ex. herança, alimentos) e extrapatrimoniais (ex. vínculo de parentesco, poder familiar), mas, com isso, serão também rompidos os laços biológicos, que somente poderão ser reconhecidos sem efeitos patrimoniais, como um direito inerente à personalidade de ter conhecida sua origem genética. ${ }^{127}$

De todo modo, a possibilidade de coexistência de filiações biológica e socioafetiva vem paulatinamente sendo admitida pela doutrina e, inclusive, recentemente, pelo Supremo Tribunal Federal, entendendo-se não serem elas excludentes entre si, uma vez que conforme destaca Daniela Paiano ${ }^{128}$ poderíamos

“(...) ao mesmo tempo ter-se o vínculo biológico com o pai ou mãe e, ao mesmo tempo o socioafetivo com o pai ou mãe de criação, padrastos e madrastas, pai e mãe adotivos, dando lugar ao que se denomina multiparentalidade."

\subsection{POSSIBILIDADE DE DUPLA FILIAÇÃO REGISTRAL}

Pretende-se, neste tópico, analisar a possibilidade de registro da filiação socioafetiva concomitantemente à filiação biológica, configurando uma dupla

\footnotetext{
${ }^{126}$ FARIAS, Cristiano Chaves de; ROSENVALD, Nelson. Op. Cit., p. 596.

${ }^{127}$ Ibid. p. 597.

${ }^{128}$ PAIANO, Daniela Braga. Op. Cit., p. 61.
} 
filiação registral que consagraria documentalmente o reconhecimento da multiparentalidade.

Segundo dispõe o artigo 10, inciso II do Código Civil, os atos judiciais e extrajudiciais que declararem ou reconhecerem a filiação devem ser averbados em registro público. Tal redação pode fundamentar, portanto, a necessidade de averbação inclusive de uma dupla filiação reconhecida no caso de uma pluriparentalidade.

Conforme destaca Cassettari ${ }^{129}$ quanto à possibilidade de registro da filiação socioafetiva, seria inconcebível para o autor o seu reconhecimento desvinculado do respectivo registro na certidão de nascimento, sob pena de se evidenciar um interesse meramente patrimonial em se declarar o vínculo, sem a devida alteração levada ao assento de nascimento.

Isso porque é o registro civil que vai conferir publicidade, servindo como meio de prova e permitindo efetivamente a produção dos efeitos regulares, oponíveis a terceiros ${ }^{130}$, do reconhecimento de uma parentalidade socioafetiva ou eventualmente de uma pluriparentalidade. ${ }^{131}$

Através do registro civil deve-se refletir a realidade fática para que se tenha segurança jurídica quanto às informações nele constantes. Por isso, não seria razoável ter o reconhecimento da socioafetividade sem a possibilidade de sua consequente alteração registral, que nada mais faz do que registrar documentalmente uma filiação já reconhecida.

Partindo do pressuposto de que é possível o reconhecimento da filiação socioafetiva, bem como seu respectivo registro, podendo esta conviver com a filiação biológica, o que gera uma multiplicidade filiatória, nada mais razoável

\footnotetext{
${ }^{129}$ CASSETTARI, Christiano. Op. Cit., p. 87.

${ }^{130}$ Isso porque $\S 1^{\circ}$ do artigo 100 da Lei de Registros Públicos (Lei $n^{\circ}$ 6.015/73) estabelece a necessidade de averbação da sentença para que possa produzir efeitos contra terceiros.

${ }^{131}$ CASSETTARI, Christiano. Op. Cit., p. 265.
} 
do que a averbação no registro civil de tal realidade também no caso da multiparentalidade.

Um dos problemas anteriormente levantados pela doutrina ao registro civil de dois pais e/ou duas mães era um óbice formal encontrado na prática cartorária de apenas haverem campos específicos para um pai e uma mãe, o que gerava um embaraço registral diante da hipótese de uma multiparentalidade. ${ }^{132}$

Ocorre que até mesmo esse "obstáculo" já experimentado faticamente foi ultrapassado com a atual padronização dos registros ${ }^{133}$, substituindo-se os antigos campos "pai" e "mãe" por campos como "filiação" e apenas "avós", no lugar de "avós paternos" e "avós maternos", permitindo o registro de dois pais e/ou duas mães e, consequentemente, a possibilidade registral da multiparentalidade.

Logo, como bem assevera Cassettari ${ }^{134}$ "se a pessoa já tinha um pai e uma mãe, hipótese de multiparentalidade, haverá o acréscimo de mais um nome no campo filiação, e de mais dois nomes no campo avós."

Dessa forma, Cassettari ${ }^{135}$ é defensor da tese de que o reconhecimento da socioafetividade ou mesmo multiparentalidade pelo juiz, implicaria em um dever de expedir, subsequentemente, mandado de averbação ao respectivo registro civil, onde também deveria constar eventual desejo de inclusão do sobrenome daquele que teve a paternidade ou maternidade reconhecida.

\footnotetext{
132 Ibid. p. 266.

${ }^{133}$ Essa atual padronização foi resultado do Provimento 2 do CNJ, de 27 de abril de 2009, alterado pelo Provimento 3, em 17 de novembro de 2009. Disponível em: $<$ http://www.cnj.jus.br///images/atos_normativos/provimento/provimento_2_27042009_26102012180 800.pdf $>$. Acesso em 15 set. 2017.

${ }^{134}$ CASSETTARI, Christiano. Op. Cit., p. 269.

135 Ibid. p. 269.
} 
Isso porque, a partir de 2009, com a alteração produzida pela Lei 11.924 (“Lei Clodovil”) na Lei 6.015/73, foi acrescido o $§ 8^{\circ}$ ao artigo $57^{136}$ desta lei, passando-se a admitir a adoção do sobrenome do padrasto ou madrasta, desde que sem exclusão de seus apelidos de família.

Destaca-se que se trata apenas de um acréscimo e não uma substituição do sobrenome anterior, de forma a não permitir dúvidas quanto à identidade da pessoa ou eximir eventuais responsabilidades do genitor. ${ }^{137}$

Tal mudança caminhou no sentido de privilegiar a multiparentalidade, reconhecendo o vínculo socioafetivo formado entre padrasto ou madrasta e os filhos advindos de relacionamento anterior da genitora ou genitor, que agora constrói nova entidade familiar caracterizada por essa multiplicidade de relações.

Motivos não existem ao Estado em coibir o desejo do filho de acrescer ao seu nome o sobrenome daquele que efetivamente o criou, como se filho biológico fosse, sendo perfeitamente compatível a utilização do nome socioafetivo e biológico concomitantemente.

Exige-se, no entanto, que haja autorização judicial apresentando "motivo ponderável" para que seja admitido tal acréscimo ao sobrenome, bem como é necessária expressa concordância do padrasto ou madrasta.

Tal circunstância, como se verá posteriormente, em nada altera o poder familiar do pai biológico, que permanece intacto mesmo após a formação dessa nova entidade familiar e até mesmo após essa eventual adoção do sobrenome do padrasto ou madrasta.

\footnotetext{
${ }^{136}$ Artigo 57, $\S 8^{\circ}$ O enteado ou a enteada, havendo motivo ponderável e na forma dos $\S \S 2^{-}$e $7^{\circ}$ deste artigo, poderá requerer ao juiz competente que, no registro de nascimento, seja averbado o nome de família de seu padrasto ou de sua madrasta, desde que haja expressa concordância destes, sem prejuízo de seus apelidos de família. (Incluído pela Lei $n^{\circ} 11.924$, de 2009)

${ }^{137}$ LÔBO, Paulo. Op. Cit., p. 85.
} 
O trecho do julgado abaixo transcrito reflete exatamente o que fora explicado nesse tópico, onde foi admitida tanto uma multiparentalidade registral, quanto a inclusão do sobrenome do pai afetivo ao nome do filho:

“(...) Resta evidente, portanto, que o arcabouço normativo pátrio, de índole constitucional, não admite qualquer discriminação entre as espécies de parentesco e filiação, tampouco veda a coexistência de relações de idêntica natureza, a exemplo da paternidade, por não estabelecer qualquer tipo de hierarquia entre elas. É dizer, diante de determinada situação concreta, na qual exista um vínculo de natureza afetiva, em que os indivíduos se reconheçam como pai e filha, fato comprovado pela longa, profícua e pública convivência entre eles (fls. 33/59), não há impedimento legal à concretização desse estado de filiação. Tampouco se impõe, nesse caso, a substituição da paternidade biológica pela afetiva, ou vice-versa, notadamente quando, como na espécie, a vontade dos requerentes é uniforme, e direciona-se ao reconhecimento da multiparentalidade. (...) A situação descrita nestes autos amolda-se, com perfeição, à hipótese de pluriparentalidade reconhecida pela doutrina e jurisprudência mais abalizadas, sendo certo que a primeira recorrente, registrada como filha de seu pai biológico, sempre o reconheceu como tal, mas, após o novo casamento de sua genitora, com o segundo autor, passou a vê-lo, também, com pai, situação compartilhada por todos aqueles com os quais conviveram, ao longo de vários anos. (...)Diante do exposto, voto no sentido de DAR PROVIMENTO ao recurso, para reformar a decisão recorrida, preservando a relação de parentesco havida entre a primeira recorrente, seu pai biológico e avós paternos, bem como para manter a averbação no registro civil determinada na origem, com relação ao parentesco socioafetivo, com o acréscimo do respectivo patronímico (Bastos), sem qualquer exclusão de sobrenomes." 138

(Grifo nosso)

138 Tribunal de Justiça do Estado da Bahia, Apelação nº 0513463-46.2014.8.05.0001, Rel. Des. Dinalva Gomes Laranjeira Pimentel, Salvador, 01 set. 2015. 


\section{ALGUNS REFLEXOS DA MULTIPARENTALIDADE NO DIREITO DE FAMÍLIA}

Em razão da falta de regramento normativo próprio que regule os efeitos advindos do reconhecimento da multiparentalidade, alguns problemas práticos surgem, quando então a doutrina e jurisprudência se apresentam de forma a contornar essa ausência de previsão legal expressa.

Assim, como veremos a seguir, dentre os defensores da possibilidade da multiparentalidade, manifestam-se de forma a reconhecer os mesmos efeitos jurídicos da paternidade biológica à paternidade socioafetiva, concomitantemente, com base nos princípios da igualdade de filiação, do melhor interesse da criança e adolescente e da dignidade da pessoa humana.

A esse respeito se posiciona Daniela Paiano ${ }^{139}$ ao defender que o reconhecimento da multiparentalidade implica em assegurar todos os direitos, obrigações e impedimentos dela decorrentes. Ou seja, o "direito de herança, alimentos, parentesco com os demais entes familiares, guarda, direito de visita, impedimentos matrimoniais", são todos institutos aplicáveis à multiparentalidade.

Nesse mesmo sentido, Belmiro Pedro Welter ${ }^{140}$ sustenta

“(...) todos os efeitos jurídicos (alimentos, herança, poder /dever familiar, parentesco, guarda compartilhada, nome, visitas, paternidade/maternidade genética e afetiva e demais direitos existenciais), das duas paternidades, devem ser outorgadas ao ser humano, na medida em que a condição humana é tridimensional, genética e afetiva e ontológica"

Em outro momento, prossegue o autor afirmando ${ }^{141}$ que

"Não reconhecer as paternidades genética e socioafetiva, ao mesmo tempo, com a concessão de TODOS os efeitos jurídicos, é negar a existência tridimensional do ser humano, que é reflexo da condição e da dignidade humana, na medida em que a

\footnotetext{
${ }^{139}$ PAIANO, Daniela Braga. Op. Cit., p. 195.

${ }^{140}$ WELTER, Belmiro Pedro. Op. Cit. p. 14.

${ }^{141}$ Ibid. p. 24.
} 
filiação socioafetiva é tão irrevogável quanto a biológica, pelo que se deve manter incólumes as duas paternidades, com o acréscimo de todos os direitos, já que ambas fazem parte da trajetória da vida humana."

Cumpre ressaltar, no entanto, que o presente trabalho pretende restringir seu estudo e destacar apenas alguns dos principais reflexos do reconhecimento da multiparentalidade no âmbito do Direito de Família, razão pela qual não serão abordados efeitos sentidos em outros ramos do Direito, como no âmbito sucessório, previdenciário e até mesmo eleitoral, os quais também envolvem infinitas discussões que merecem um estudo mais aprofundado em outra oportunidade.

Como bem assevera Schreiber e Lustosa ${ }^{142}$, embora a multiparentalidade seja realidade cada vez mais presente na contemporaneidade, ainda há grande resistência em reconhecê-la, principalmente em razão da concepção de que a família nuclear tradicional seria o modelo ideal e, assim, uma multiplicidade de vínculos de filiação geraria diversos problemas práticos.

Por isso a necessidade de abordarmos as consequências da multiparentalidade no direito brasileiro, visando superar os preconceitos existentes, através de soluções técnicas que podem ser aplicadas a esse novo instituto familiar, seja quanto ao exercício do poder familiar, obrigação alimentar e ao direito de guarda e visitação, como se verá a seguir.

\subsection{EXERCÍCIO DO PODER FAMILIAR}

Em uma tentativa conceitual do poder familiar, Caio Mário ${ }^{143}$ o define como "complexo de direitos e deveres quanto à pessoa e bens do filho, exercidos pelos pais na mais estreita colaboração, e em igualdade de condições"

\footnotetext{
${ }^{142}$ SCHREIBER, Anderson; LUSTOSA, Paulo Franco. Op. Cit., p. 850.

${ }^{143}$ PEREIRA, Caio Mário da Silva. Op. Cit., p. 500.
} 
Pode-se dizer que o conteúdo do poder familiar sofreu modificação com a atual concepção do filho como sujeito de direito e não mais objeto de direito, devendo ser desempenhado em observância ao melhor interesse do filho e não mais de acordo com a supremacia da vontade paterna. ${ }^{144}$

Ou seja, atualmente o poder familiar é visto como um poder-função ou direito-dever, sendo um direito personalíssimo dos pais, mas que se encontra limitado na personalidade dos filhos, uma vez que deve servir aos seus interesses. $^{145}$

Segundo leciona Dias ${ }^{146}$, o poder familiar seria irrenunciável, intransferível, inalienável e imprescritível, podendo decorrer da paternidade natural, filiação legal e até mesmo da socioafetiva.

Destaca-se ainda a crítica que se faz doutrinariamente acerca da nomenclatura utilizada pelo Código, majoritariamente defendendo-se que uma expressão mais adequada seria autoridade parental, em detrimento de poder familiar, por refletir menos um poder e mais um dever/múnus dos pais em relação aos filhos, assim como melhor representaria o princípio da proteção integral. ${ }^{147}$

No que tange à titularidade e exercício do poder familiar, o artigo 1.631 do $\mathrm{CC} / 02^{148}$ dispõe que a autoridade parental cabe igualmente a ambos os genitores, o que permanece inalterado mesmo após eventual dissolução dos vínculos afetivos entre eles.

\footnotetext{
${ }^{144}$ MADALENO, Rolf. Op. Cit., p. 654.

145 DIAS, Maria Berenice. Op. Cit., p. 461.

146 Ibid. p. 462.

${ }^{147}$ Partilham de tal entendimento, por exemplo, Caio Mário, Maria Berenice Dias e Paulo Lôbo.

148 Art. 1.631. Durante o casamento e a união estável, compete o poder familiar aos pais; na falta ou impedimento de um deles, o outro o exercerá com exclusividade.

Parágrafo único. Divergindo os pais quanto ao exercício do poder familiar, é assegurado a qualquer deles recorrer ao juiz para solução do desacordo.
} 
Isso porque a convivência não é pressuposto ao exercício do poder familiar, permanecendo este íntegro, exceto quanto ao direito de ter o filho em sua companhia, conforme pode ser deduzido da redação do artigo 1.632 do $\mathrm{CC} / 02^{149}$

Sendo assim, mesmo diante de uma família reconstituída a autoridade parental do genitor permanece intacta. Não poderia o genitor separado abrir mão do poder familiar em detrimento do padrasto ou madrasta, uma vez que, conforme destacado, não se trata de direito disponível. Só haveria a concentração da autoridade parental aos padrastos e madrastas diante de uma eventual perda do poder familiar, de acordo com as hipóteses legais, seguida de uma adoção unilateral. ${ }^{150}$

Segundo Dias ${ }^{151}$, caso um dos genitores detentor da guarda do filho venha a estabelecer uma nova família, persiste o princípio da incomunicabilidade do poder familiar, consagrado no artigo 1.636 do CC/ $02^{152}$, vedando a lei a interferência do novo parceiro/a no exercício da autoridade parental do genitor, uma vez que não há a transferência do autoridade parental com essa recomposição familiar.

É justamente nesse sentido que se posiciona Albuquerque ${ }^{153}$ ao afirmar que a relação paterno-filial e, consequentemente, a autoridade parental, que é inerente ao vínculo familiar, está plenamente desvinculada da relação afetiva

\footnotetext{
${ }^{149}$ Art. 1.632. A separação judicial, o divórcio e a dissolução da união estável não alteram as relações entre pais e filhos senão quanto ao direito, que aos primeiros cabe, de terem em sua companhia os segundos.

${ }^{150}$ LÔBO, Paulo. Op. Cit., p. 84.

${ }^{151}$ DIAS, Maria Berenice. Op. Cit., p. 465.

${ }^{152}$ Art 1.636. O pai ou a mãe que contrai novas núpcias, ou estabelece união estável, não perde, quanto aos filhos do relacionamento anterior, os direitos ao poder familiar, exercendo-os sem qualquer interferência do novo cônjuge ou companheiro.

Parágrafo único. Igual preceito ao estabelecido neste artigo aplica-se ao pai ou à mãe solteiros que casarem ou estabelecerem união estável.

153 ALBUQUERQUE, Fabíola Santos. Poder familiar nas famílias recompostas e o artigo 1636 do CC/02. Disponível em: <http://www.ibdfam.org.br/_img/congressos/anais/117.pdf>. Acesso em 14 set. 2017.
} 
ou estado civil adotado pelos pais, não se permitindo ao novo parceiro tal ingerência no exercício daquele que não é o guardião, em respeito ao princípio do melhor interesse da criança ou adolescente.

Ocorre que, quando se fala em multiparentalidade, ou seja, múltiplos vínculos de filiação reconhecidos, há que se analisar como se daria o exercício do poder familiar, principalmente em virtude da referida regra de incomunicabilidade do poder familiar que precisa se compatibilizar com essa realidade de famílias reconstituídas.

Dessa forma, Penna e Araujo ${ }^{154}$ falam que nesse caso existiriam "múltiplas autoridades parentais", estendendo-se ao padrasto e/ou madrasta o poder familiar quando existente relação de filiação entre eles, constituída através da posse de estado de filho, ou seja, quando manifestado faticamente o exercício da autoridade parental.

Conforme destacam os autores, "o reconhecimento da multiparentalidade, na atual ordem legislativa brasileira, não implica necessariamente na extensão do poder parental ou familiar", mas sim o exercício da relação socioafetiva pelos pais afins que, desempenhando com frequência os atos inerentes a autoridade parental, acarretariam na constituição do poder familiar. ${ }^{155}$

Nesse sentido, o Enunciado $\mathrm{n}^{\circ} 06$ do IBDFAM estabelece que o reconhecimento da filiação socioafetiva também implicaria na aplicação a ela de todos os direitos e deveres inerentes à autoridade parental. ${ }^{156}$

Seguindo essa mesma orientação, pelo trecho que se destaca do seguinte julgado é possível extrair que o reconhecimento da paternidade socioafetiva

\footnotetext{
${ }^{154}$ PENNA, Saulo Versiani; ARAUJO, Deborah Nayara dos Reis. Op. Cit., p. 35.

155 Ibid. p. 39.

${ }^{156}$ Enunciado $\mathrm{n}^{\circ} 06$ do IBDFAM: "Do reconhecimento jurídico da filiação socioafetiva decorrem todos os direitos e deveres inerentes à autoridade parental."
} 
concomitante à biológica implicaria nesse exercício conjunto do poder familiar, conforme dispõe:

“(...) uma vez reconhecida a paternidade, esta não pode ser uma meia paternidade ou uma paternidade parcial. Se é pai, obviamente, é pai para todos os efeitos e não apenas para alguns efeitos. No caso dos autos a situação é até relativamente cômoda, na medida em que todas as partes concordam com esta solução. Além disso, ambos os pais mantém relacionamento respeitoso e amigável, o que certamente facilitará o exercício da autoridade parental (poder familiar) agora não somente pelos dois genitores, mas também pelo requerente (pai socioafetivo), todos (os três) igualmente responsáveis pelo bem estar do adotando."

Ana Carolina Teixeira ${ }^{158}$ chega a sugerir que se faça uma alteração legislativa no supramencionado art. 1.636 do CC/02 para que se adeque a norma aos novos arranjos familiares, em prol do melhor interesse do menor, viabilizando o exercício da autoridade parental por todos os envolvidos.

Nesse sentido, leciona Daniela Paiano ${ }^{159}$ que

"em casos de famílias reconstituídas, pode existir uma ingerência do padrasto ou madrasta na vida do filho, de forma que a parte final do art. 1.636 deveria ser repensada para estender os efeitos do poder familiar nessas novas relações. Pai e mãe afim ocupam um lugar na vida desses novos filhos. Esse também é um motivo positivo para o reconhecimento da possibilidade da multiparentalidade."

O Projeto de Lei $n^{\circ} 2.285 / 07$ (Estatuto das Famílias) inclusive prevê uma alteração nessa direção ao estabelecer, em seu artigo 91, que "constituindo os pais nova entidade familiar, os direitos e deveres decorrentes da autoridade parental são exercidos com a colaboração do novo cônjuge ou convivente ou parceiro". Assim também dispõe o artigo 70 do Projeto de Lei n 407/13 (Estatuto das Famílias, de iniciativa do IBDFAM), segundo o qual "o cônjuge ou companheiro pode compartilhar da autoridade parental em relação aos enteados, sem prejuízo do exercício da autoridade parental dos pais ”.

\footnotetext{
157 Tribunal de Justiça do Estado do Paraná, Autos nº 0038958-54.2012.8.16.0021, Juiz Dr. Sérgio Luiz Kreuz, Cascavel, 20 fev. 2013.

158 TEIXEIRA, Ana Carolina Brochado; RODRIGUES, Renata de Lima. Op. Cit., p. 28.

${ }^{159}$ PAIANO, Daniela Braga. Op Cit., p. 188.
} 
É inevitável que no seio de famílias multiparentais os "padrastos/madrastas" assumam funções inerentes ao poder familiar, sendo exercido concomitante a autoridade parental pelos pais biológicos e socioafetivos, o que pode nos levar a um questionamento acerca de uma eventual superposição de papéis parentais, em virtude de possíveis conflitos de decisão que possam surgir entre todos os envolvidos.

Assim, diante de eventuais conflitos no exercício do poder familiar, errôneo seria solucioná-los dando prevalência à alguma filiação em detrimento de outra, uma vez que além de representar uma afronta ao princípio da igualdade filiatória, desrespeitaria um pré-requisito do próprio instituto da multiparentalidade, que tem como pressuposto a coexistência de maneira igualitária entre as filiações biológica e socioafetiva, sem qualquer hierarquia entre elas.

Logo, a melhor solução diante de um caso em que haja divergência na tomada de decisão entre pais biológicos e socioafetivos seria a aplicação analógica do parágrafo único do artigo 1.631 do $\mathrm{CC} / 02$, recorrendo-se ao suprimento judicial para a solução do desacordo. ${ }^{160}$

Ocorre que, como bem advertem Schreiber e Lustosa ${ }^{161}$, tal solução já não é o ideal nos casos de biparentalidade, uma vez que representa uma excessiva judicialização da vida familiar, o que se agrava nos casos de uma multiparentalidade, diante da maior possibilidade de dissenso existente.

Assim, sustentam os autores que o mais recomendável seria o emprego de mecanismos extrajudiciais de resolução de conflitos, seja no caso da biparentalidade ou multiparentalidade, devendo o suprimento judicial ser utilizado apenas excepcionalmente.

\footnotetext{
${ }^{160}$ PENNA, Saulo Versiani; ARAUJO, Deborah Nayara dos Reis. Op. Cit., p. 39.

${ }^{161}$ SCHREIBER, Anderson; LUSTOSA, Paulo Franco. Op. Cit., p. 866.
} 
Por fim, segundo destacam Cassettari ${ }^{162}$ e Penna e Araujo ${ }^{163}$, a multiparentalidade, por ter como pressuposto a igualdade entre os vínculos de filiação, também implicará em submeter os pais socioafetivos às mesmas hipóteses de suspensão (art. 1.637, CC/02) e perda do poder familiar (art. $1.638, \mathrm{CC} / 02$ ) a que estão vinculados os pais biológicos.

\subsection{OBRIGAÇÃO ALIMENTAR}

Dada a importância que representa, a obrigação alimentar dos pais em relação aos filhos menores é estabelecida na própria Constituição Federal, conforme depreende-se da seguinte redação:

“Art. 227. É dever da família, da sociedade e do Estado assegurar à criança, ao adolescente e ao jovem, com absoluta prioridade, o direito à vida, à saúde, à alimentação, à educação, ao lazer, à profissionalização, à cultura, à dignidade, ao respeito, à liberdade e à convivência familiar e comunitária, além de colocá-los a salvo de toda forma de negligência, discriminação, exploração, violência, crueldade e opressão."

(Grifo nosso)

Segundo Dias ${ }^{164}$, quando pensamos em obrigação alimentar sempre nos remetemos ao pai registral, que nem sempre corresponderá ao pai biológico, uma vez que a filiação socioafetiva cada vez mais vem sendo prestigiada e isso vai refletir também na obrigação de prestar alimentos.

Destaca-se ainda que os artigos $1.694^{165}$ e $1.696^{166}$ do Código Civil quando se referem à obrigação alimentar em virtude do parentesco, não fazem qualquer distinção entre parentesco biológico ou socioafetivo, razão pela qual se compreende existente o dever de prestar alimentos também na filiação socioafetiva.

\footnotetext{
${ }^{162}$ CASSETTARI, Christiano. Op. Cit., p. 261.

${ }^{163}$ PENNA, Saulo Versiani; ARAUJO, Deborah Nayara dos Reis. Op. Cit., p. 40.

${ }^{164}$ DIAS, Maria Berenice. Op Cit., p. 583.

165 Art. 1.694. Podem os parentes, os cônjuges ou companheiros pedir uns aos outros os alimentos de que necessitem para viver de modo compatível com a sua condição social, inclusive para atender às necessidades de sua educação.

${ }^{166}$ Art. 1.696. O direito à prestação de alimentos é recíproco entre pais e filhos, e extensivo a todos os ascendentes, recaindo a obrigação nos mais próximos em grau, uns em falta de outros.
} 
Nesse sentido também se posiciona Caio Mário ${ }^{167}$ ao afirmar que a solidariedade social e o princípio da não discriminação dos filhos fundamentam a obrigação alimentar também no caso da filiação socioafetiva.

Assim, uma vez comprovada a vinculação socioafetiva, poderia o filho pleitear alimentos face ao pai afetivo, entendimento este inclusive já consolidado através do Enunciado n ${ }^{\circ} 341$ da IV Jornada de Direito Civil ${ }^{168}$.

Dessa forma, conforme destaca Maria Berenice Dias ${ }^{169}$, a tendência atual é se reconhecer a concorrência da obrigação alimentar do pai registral, biológico e afetivo, podendo ser reivindicados alimentos do genitor biológico diante de uma menor capacidade do pai afetivo. Isso porque, os alimentos, uma vez que decorrem do princípio da solidariedade familiar, vão ser devidos independentemente da origem do vínculo.

Ressalta ainda a autora ${ }^{170}$ que moderna corrente doutrinária defende que haveria o que se denomina "paternidade alimentar", segundo a qual a concepção geraria dever do pai biológico à prestação alimentícia, ainda que este "não saiba da existência do filho nem de seu nascimento e mesmo que a paternidade tenha sido assumida por terceiros".

À guisa de esclarecimento, a paternidade alimentar corresponderia a um reconhecimento da parentalidade com fins exclusivamente alimentares. Assim, Rolf Madaleno ${ }^{171}$ partilhando desse entendimento sustenta

"O pai biológico e de nenhum vínculo de amor pode ser convocado a prestar sustento integral ao seu filho de sangue, sem que a obrigação material importe em qualquer possibilidade de retorno à sua família natural, mas que apenas garanta o provincial

\footnotetext{
${ }^{167}$ PEREIRA, Caio Mario. Op. Cit., p. 635.

${ }^{168}$ Enunciado n 341: "Para os fins do art. 1.696, a relação socioafetiva pode ser elemento gerador de obrigação alimentar.”

${ }^{169}$ DIAS, Maria Berenice. Op. Cit., p. 583.

${ }^{170}$ Ibid. p. 583.

171 MADALENO, Rolf. Laços que ficam e paternidade alimentar. Disponível em: < http://www.rolfmadaleno.com.br/novosite/conteudo.php?id=998>. Acesso em 23 out. 2017.
} 
efeito material de assegurar ao filho rejeitado a vida digna, como nas gerações passadas, em que ele só podia pedir alimentos do seu pai que era casado e o rejeitara."

Ou seja, seguindo esse raciocínio, seria plenamente possível ao menor reivindicar alimentos do genitor biológico, caso haja uma insuficiência econômica do pai socioafetivo, que não possui condições de cumprir satisfatoriamente com a real necessidade alimentar do filho que acolheu com base no afeto, situação na qual não lhe falta amor, mas sim dinheiro. ${ }^{172}$

No que concerne à obrigação alimentar diante de uma pluriparentalidade, Araujo e Penna ${ }^{173}$ defendem, com base na igualdade de filiação, que os pais e mães afetivos possuem obrigação assistencial integral em relação aos filhos menores, tal qual os pais biológicos. Nesse sentido, dispõem que tal obrigação, que se revela concorrente entre os pais biológicos e socioafetivos, permanece mesmo diante de uma nova dissolução familiar, devendo se observar os pressupostos legais de necessidade dos alimentandos, capacidade dos alimentantes e proporcionalidade no arbitramento judicial.

Como não existe regramento normativo próprio que regule especificamente as relações de parentesco plurais, no caso da multiparentalidade, são a ela aplicáveis os mesmos dispositivos regentes das relações singulares, previstas no ordenamento jurídico.

Logo, pelas lições de Daniela Paiano ${ }^{174}$, resta claro que as regras dos artigos 1.694 e seguintes do Código Civil são aplicáveis também à multiparentalidade, podendo o filho demandar alimentos de qualquer de seus pais, sejam biológicos ou socioafetivos, na medida de sua necessidade.

\footnotetext{
${ }^{172}$ Ibid. Disponível em: < http://www.rolfmadaleno.com.br/novosite/conteudo.php?id=998>. Acesso em 23 out. 2017.

${ }^{173}$ PENNA, Saulo Versiani; ARAUJO, Deborah Nayara dos Reis. Op. Cit., p. 41.

${ }^{174}$ PAIANO, Daniela Braga. Op. Cit., p. 198.
} 
Diante de múltiplos vínculos de filiação, portanto, entende-se que subsiste direito ao filho de pleitear alimentos do pai socioafetivo, uma vez que é dever daquele que desempenha as funções parentais a prestação alimentícia, não anulando a responsabilidade do pai biológico, que persistiria concomitantemente e em complementação à verba alimentar ou ainda em decorrência de uma impossibilidade dos pais afetivos. ${ }^{175}$

Diante disso, é possível afirmar, como bem determina Daniela Paiano ${ }^{176}$, que

"uma vez reconhecida a multiparentalidade, o direito aos alimentos se estenderá ao filho reconhecido, podendo ele pleitear o seu direito, na medida de sua necessidade. Esse direito é um desdobramento do princípio da igualdade jurídica entre os filhos e o da não discriminação. Ou seja, o direito aos alimentos seria uma consequência da filiação multiparental reconhecida."

Cassettari ${ }^{177}$ leciona que, no entanto, não vai haver solidariedade ${ }^{178}$ entre os múltiplos pais envolvidos na multiparentalidade, uma vez que a pensão alimentícia será paga por qualquer deles, conforme livre escolha do alimentado em face de quem optar por acionar em eventual ação alimentícia, devendo os alimentos serem fixados de acordo com a necessidade do alimentado e possibilidade do alimentante.

O autor utiliza como argumento uma questão problemática prática, pois sustenta que um fracionamento da obrigação alimentícia entre os diversos sujeitos que uma multiparentalidade pode comportar, aumentaria os riscos de um inadimplemento.

\footnotetext{
${ }^{175}$ DIAS, Maria Berenice. Op. Cit., p. 583.

${ }^{176}$ PAIANO, Daniela Braga. Op. Cit., p. 191.

${ }_{177}^{177}$ CASSETTARI, Christiano. Op. Cit., p. 260.

${ }^{178}$ Isso porque, segundo dispõe o art. $265, \mathrm{CC} / 02$, a solidariedade não pode ser presumida, decorrendo da lei ou da vontade das partes.
} 
Sendo assim, interpreta a redação do art. 1.698 do $\mathrm{CC} / 02^{179}$ de forma a obrigar apenas um dos pais, caso este possua condições de suportar tal encargo sozinho. Isso porque o referido artigo estabelece que, sendo várias pessoas obrigadas, deveriam estas concorrer na proporção de seus respectivos recursos. Assim, se um dos pais possui condições de prestar sozinho, assim deveria fazêlo, possibilitando-se ainda ao escolhido chamar os demais obrigados a ingressar no feito, desde que provada sua impossibilidade financeira, quando então admitir-se-ia uma possível divisão. ${ }^{180}$

Frise-se ainda que o reconhecimento da multiparentalidade se manifesta como uma via de mão dupla, ou seja, atrelados aos direitos assegurados aos filhos em relação aos múltiplos pais, estão também os direitos desses múltiplos pais em relação aos filhos.

Por isso, entende-se que se aplica igualmente às famílias pluriparentais a solidariedade mútua entre pais e filhos, o que implica em uma responsabilidade alimentar dos filhos para com os pais (biológicos e/ou afetivos), independentemente de quantos sejam, mesmo que possa representar um encargo excessivo. ${ }^{181}$

\subsection{FIXAÇÃO DE GUARDA E DIREITO DE VISITAÇÃO}

Importante discussão que também permeia a multiparentalidade consiste na fixação de guarda e no direito à visitação dos pais biológicos e afetivos diante de múltiplos laços parentais, havendo ainda que se cogitar do advento de uma possível nova dissolução familiar.

\footnotetext{
${ }^{179}$ Art. 1.698. Se o parente, que deve alimentos em primeiro lugar, não estiver em condições de suportar totalmente o encargo, serão chamados a concorrer os de grau imediato; sendo várias as pessoas obrigadas a prestar alimentos, todas devem concorrer na proporção dos respectivos recursos, e, intentada ação contra uma delas, poderão as demais ser chamadas a integrar a lide.

${ }^{180}$ CASSETTARI, Christiano. Op. Cit., p. 260.

${ }^{181}$ PENNA, Saulo Versiani; ARAUJO, Deborah Nayara dos Reis. Op. Cit., p. 41.
} 
Tal matéria vem regulada no capítulo XI (Livro IV, Título I, Subtítulo I) do Código Civil quando trata da proteção da pessoa dos filhos, sem, entretanto, conter previsão expressa para o caso de múltiplos vínculos de filiação, estabelecendo apenas pelo art. 1.583 que a guarda pode ser unilateral ou compartilhada, ambas definidas em seu $§ 1^{\circ} .{ }^{182}$

Ocorre que, apesar da evidente maior dificuldade de compatibilizar o tema da guarda e visitação quando presentes mais vínculos parentais, o critério a ser adotado será sempre o melhor interesse da criança e do adolescente, em respeito ao princípio da proteção integral consagrado do artigo 227 da Constituição Federal. ${ }^{183}$

O instituto da guarda compartilhada sofreu recente alteração legislativa promovida, primeiramente, pela Lei 11.698/08 e, posteriormente, pela Lei 13.058/14, passando a ter certa preferência em relação à guarda unilateral, quando se coadunar ao melhor interesse do filho. Assim, via de regra, conforme leciona Daniela Paiano ${ }^{184}$

“(...) nos casos de multiparentalidade, a guarda poderá ser exercida de forma compartilhada por todos os pais reconhecidos ou, então, de forma compartilhada pelos pais que vivem sobre um mesmo teto e com direito de visita ao outro"

Cogitando-se ainda do advento de um novo rompimento familiar, poderíamos pensar em um exercício de guarda compartilhada entre todos os pais separados ou a guarda exclusiva de um ou mais de um e direito à visitação dos demais, conforme se demonstre, pela análise do caso concreto, a solução mais favorável ao filho.

\footnotetext{
${ }^{182}$ Art. 1.583. A guarda será unilateral ou compartilhada..§ 1o Compreende-se por guarda unilateral a atribuída a um só dos genitores ou a alguém que o substitua (art. 1.584, § 5o) e, por guarda compartilhada a responsabilização conjunta e o exercício de direitos e deveres do pai e da mãe que não vivam sob o mesmo teto, concernentes ao poder familiar dos filhos comuns.

${ }^{183}$ SCHREIBER, Anderson; LUSTOSA, Paulo Franco. Op. Cit., p. 868.

${ }^{184}$ PAIANO, Daniela Braga. Op. Cit., p. 195.
} 
Além disso, partindo do pressuposto de que o poder familiar cabe igualmente a todos os múltiplos pais e mães, sejam estes biológicos ou afetivos, conforme destacado anteriormente, uma consequência lógica será também da mesma forma compreender quanto ao direito de guarda e visitação, uma vez que expressamente decorrem do exercício da autoridade parental. ${ }^{185}$

Nesse sentido, Penna e Araujo ${ }^{186}$ sustentam que a guarda deve ser fixada sempre visando o melhor interesse do filho, o que deve ser analisado casuisticamente, observadas as particularidades que caracterizam uma família pluriparental, devendo ser assegurado ao menor a solução que melhor realize seu desenvolvimento saudável e harmônico.

Assim, em que pese a preferência legalmente estabelecida da guarda compartilhada por ser a modalidade que, via de regra, melhor assegura os interesses do menor, esta não deve ser imposta sem uma avaliação específica do caso concreto.

No mais, seguindo novamente a lógica de igualdade entre as filiações biológica e socioafetiva, que fundamenta o fenômeno da multiparentalidade, também quanto à guarda e visitação nenhuma distinção poderia ser feita, a priori, em razão da origem do parentesco.

Corroborando tal entendimento, Schreiber e Lustosa ${ }^{187}$ sustentam que seria descabida a tentativa de estabelecer critérios em abstrato e a priori, específicos para as situações de multiparentalidade, uma vez que a análise deve ser feita à luz do caso concreto, com vistas à proteção dos interesses do menor.

\footnotetext{
${ }^{185}$ Art. 1.634. Compete a ambos os pais, qualquer que seja a sua situação conjugal, o pleno exercício do poder familiar, que consiste em, quanto aos filhos: II - exercer a guarda unilateral ou compartilhada nos termos do art. 1.584;

${ }^{186}$ PENNA, Saulo Versiani; ARAUJO, Deborah Nayara dos Reis. Op. Cit., p. 41.

${ }^{187}$ SCHREIBER, Anderson; LUSTOSA, Paulo Franco. Op. Cit., p. 868.
} 
É justamente, seguindo essa orientação, que se posiciona Cassettari ${ }^{188}$ ao afirmar

“(...) verifica-se que tanto o pai quanto a mãe socioafetivos terão direito à guarda do filho, pois não há preferência para o exercício de guarda, unilateral ou compartilhada de uma criança ou adolescente em decorrência da parentalidade ser biológica ou afetiva, pois o que deve ser atendido é o melhor interesse da criança."

Assim, diante de múltiplos vínculos parentais, para além do direito à guarda, também quanto ao direito à visitação nenhuma diferenciação apriorística pode ser feita quanto ao tipo de filiação, não podendo ser retirado seu direito a conviver com o filho, bem como dirigir sua criação e educação, o que, conforme exposto, decorre do próprio poder familiar, pois o que sempre deve se priorizar é o melhor interesse do menor.

Saliente-se, por fim, que tal direito de visitação também será extensível aos avós, sejam biológicos ou socioafetivos, uma vez que o reconhecimento da multiparentalidade implicará na ampliação dos vínculos de parentesco do filho, conforme destacado outrora.

${ }^{188}$ CASSETTARI. Christiano. Op. Cit., p.135. 


\section{ANÁLISE JURISPRUDENCIAL DO RECURSO EXTRAORDINÁRIO 898.060/SC (REPERCUSSÃO GERAL 622)}

Em sessão realizada em 21 de setembro de 2016, de relatoria do Ministro Luiz Fux, o Supremo Tribunal Federal se reuniu para a análise do Recurso Extraordinário 898.060/SC, ao qual foi reconhecida a Repercussão Geral 622, para que se deliberasse sobre uma eventual "prevalência da paternidade socioafetiva em detrimento da paternidade biológica".

Ocorre que, conforme destaca Calderón ${ }^{189}$, a Corte Suprema, ao analisar a referida questão, optou por não dar prevalência a qualquer dos vínculos, mas sim reconhecer a igualdade e possibilidade de coexistência entre a filiação biológica e socioafetiva.

A tese de repercussão geral aprovada para seguir de parâmetro e ser aplicada em casos semelhantes foi fixada pela Corte com a seguinte redação:

“A paternidade socioafetiva, declarada ou não em registro público, não impede o reconhecimento do vínculo de filiação concomitante baseado na origem biológica, com os efeitos jurídicos próprios." 190

Entretanto, conforme destacado por Schreiber ${ }^{191}$, a partir da análise do julgamento e da tese final aprovada, percebe-se que o Supremo Tribunal Federal não se demonstrou plenamente coeso, uma vez que marcado por algumas propostas antagônicas e reviravoltas, o que revela que a visão do tema, entre os próprios Ministros, não é necessariamente unívoca.

189 CALDERÓN, Ricardo. Reflexos da decisão do STF que acolheu a socioafetividade e a multiparentalidade. Disponível em: $<$ http://www.ibdfam.org.br/artigos/1155/Reflexos + da + decisão + do + STF + que + acolheu $+\mathrm{a}+$ socioafetivid soc $+\mathrm{e}+\mathrm{a}+$ multiparentalidade $>$. Acesso em 18 out. 2017.

190 Publicada no Informativo $\mathrm{n}^{\circ} 840$ do STF. Disponível em: < http://www.stf.jus.br/arquivo/informativo/documento/informativo840.htm>. Acesso em 25 out. 2017.

191 SCHREIBER, Anderson. STF, Repercussão Geral 622: a Multiparentalidade e seus Efeitos. Disponível em: <http://www.cartaforense.com.br/conteudo/artigos/stf-repercussao-geral-622-amultiparentalidade-e-seus-efeitos/16982>. Acesso em 24 out. 2017. 
De todo modo, a conclusão ao final obtida por maioria dos votos representou um significativo avanço no sentido de se consagrar um Direito de Família efetivamente plural e democrático, na medida em que rompeu com o estereótipo tradicional, segundo o qual cada pessoa poderia nutrir apenas um vínculo paterno e um materno.

Assim, analisaremos mais detidamente as discussões suscitadas no referido julgamento que permitiram o alcance da tese fixada pela Corte Suprema, que, mais uma vez, exerceu sua função de não fechar os olhos para a realidade, acolhendo a multiparentalidade como uma entidade familiar que embora seja uma realidade incontestável, não consegue se enquadrar aos modelos fechados e pré-estabelecidos do ordenamento jurídico brasileiro. ${ }^{192}$

No caso concreto, o Supremo Tribunal Federal, por maioria dos votos, negou provimento ao Recurso Extraordinário ${ }^{\circ}$ 898.060/SC, em que um pai biológico recorria contra acórdão que estabeleceu sua paternidade e a ela reconheceu efeitos patrimoniais, independentemente do vínculo paterno socioafetivo, existente por mais de vinte anos. ${ }^{193}$

Sustentava o recorrente que fosse mantido apenas o vínculo biológico sem os efeitos patrimoniais dele decorrentes, uma vez que a própria filha afirmava não pretender o desfazimento do vínculo com o pai socioafetivo, defendendo a preponderância da socioafetividade como forma de evitar demandas que buscassem o reconhecimento ou não da paternidade em função, meramente, de seus efeitos materiais.

O Instituto Brasileiro de Direito de Família (IBDFAM), atuando na qualidade de amicus curiae, afirmou a necessidade de ambas as paternidades, socioafetiva e biológica, serem reconhecidas em igualdade de condições, sem

\footnotetext{
${ }^{192}$ SCHREIBER, Anderson; LUSTOSA, Paulo Franco. Op. Cit., p. 869.

${ }^{193}$ CASSETTARI, Christiano. Op. Cit., p. 191.
} 
qualquer hierarquia, em princípio, nos casos em que ambas apresentem vínculos socioafetivos relevantes. ${ }^{194}$

Por oportuno, cabe também ressaltar a manifestação do Procurador Geral da República, Rodrigo Janot, ao defender a possibilidade de reconhecimento de mais de um vínculo parental em relação a um mesmo sujeito, uma vez que a Constituição não admite restrições injustificadas à proteção dos diversos modelos familiares, destacando ainda ser inviável estabelecer, em abstrato, a prevalência entre as paternidades biológica ou socioafetiva, pois isso apenas poderia ser feito a partir da análise do caso concreto. ${ }^{195}$

O relator, Ministro Luiz Fux, foi seguido pela maioria dos votos ao negar provimento ao recurso extraordinário e reconhecer a dupla parentalidade, restando vencidos os Ministros Edson Fachin e Teori Zavascki.

O Ministro Edson Fachin, votando pelo provimento parcial do recurso, assentando-se também na ausência de hierarquização entre os critérios de filiação, entendeu pela prevalência do vínculo socioafetivo no caso concreto. Isso porque, segundo o ministro, o vínculo biológico “pode ser hábil, por si só, a determinar o parentesco jurídico, desde que na falta de uma dimensão relacional que a ele se sobreponha", como afirmou ocorrer no presente caso. Assim, destacou os casos de inseminação artificial heteróloga e de adoção, como exemplos de situações em que se verifica uma distinção entre a figura do ascendente genético e a figura de pai, e onde o vínculo biológico não prevalece, nem coexiste com outros critérios, ou seja, não geraria paternidade do ponto de vista jurídico.

Dessa forma, afirma o Ministro Edson Fachin

\footnotetext{
${ }^{194}$ CASSETTARI, Christiano. Op. Cit., p. 192.

195 Ibid. p. 192.
} 
“o parentesco socioafetivo não é prioritário, nem subsidiário à paternidade biológica, nem tampouco um parentesco de segunda classe. Trata-se de fonte de paternidade, de maternidade, de filiação dotada da mesma dignidade jurídica da adoção constituída judicialmente e que se afasta, na fixação do parentesco jurídico, do vínculo biológico. Havendo vínculo socioafetivo com um pai (é o caso) e vinculo biológico com outro genitor (é o caso) entendo que é o parentesco socioafetivo que se impõe juridicamente. O parentesco socioafetivo não é menos parentesco do que aquele estabelecido por adoção formal. Assim como o filho adotivo não pode constituir paternidade com outrem sob fundamento biológico, assim também não pode o filho socioafetivo"

Portanto, divergindo do relator, Fachin entendeu pela prevalência da paternidade socioafetiva, resguardando o direito ao conhecimento da origem biológica. No entanto, apesar de não ter reconhecido, no presente caso, hipótese de multiparentalidade, ressalva que não se pretendeu negar sua possibilidade, mas, segundo o entendimento do ministro, esta se apresentaria em situações onde haveria um desejo tanto do pai biológico, como do pai socioafetivo de serem pais, além de ser medida que melhor atende ao interesse da criança ou seja consentido pelo adolescente.

Também vencido o Ministro Teori Zavascki, votando pelo provimento integral do recurso, destacou que a paternidade biológica não geraria necessariamente a relação de paternidade do ponto de vista jurídico e com as consequências decorrentes, defendendo a necessidade de se preservar a paternidade socioafetiva existente, já que não seria ela menos importante que qualquer outro vínculo parental. ${ }^{196}$

Entretanto, o entendimento final firmado foi no sentido de que a “existência da paternidade socioafetiva não exime a responsabilidade do pai biológico"197, admitindo-se a sua concomitância de maneira a abraçar a possibilidade de ocorrência da multiparentalidade, com todos os efeitos patrimoniais e extrapatrimoniais que tal reconhecimento implica.

\footnotetext{
${ }^{196}$ CASSETTARI, Christiano. Op. Cit., p. 193.

${ }^{197}$ Ibid. p. 194.
} 
Se antes havia divergência jurisprudencial na aceitação da multiparentalidade, após o posicionamento firmado pelo Supremo Tribunal Federal, não cabe mais questionamento quanto a sua plena compatibilidade dentro do ordenamento jurídico brasileiro.

Ressalte-se, por oportuno, algumas premissas levantadas durante os debates no referido julgamento e que, portanto, permitiram a adoção do entendimento prevalecente.

A maioria dos ministros se posicionou de maneira a defender que não poderia o genitor se desertar de seus deveres legais, em virtude do reconhecimento de uma paternidade socioafetiva. Isso porque, o pai biológico, no momento em que gera o filho, cria com ele um vínculo permanente, a partir do qual decorrerão responsabilidades que persistem, independentemente de outro vínculo socioafetivo existente.

Nessa esteira, Gilmar Mendes chega a sustentar que o não reconhecimento da paternidade biológica, no presente caso, representaria um estímulo à paternidade irresponsável, permitindo-se ao indivíduo se eximir de uma responsabilidade em virtude de uma situação fática que se apresentaria.

Desse modo, o fato de ter o filho recebido cuidado e afeto de pai socioafetivo não pode ter o condão de afastar o direito de perseguir o cumprimento das obrigações legais também pelo pai biológico. Situação essa ainda mais evidente quando se verifica, por exemplo, uma insuficiência do pai afetivo em atender às necessidades do filho, sendo imperioso a ele reconhecer a possibilidade de obter uma eventual complementação do pai biológico.

Neste recente e paradigmático julgamento, portanto, o Supremo Tribunal Federal aprovou tese fundamental à evolução do Direito de Família no sentido de se adequar às novas necessidades sociais, cabendo extrair dele três principais aspectos, quais sejam: o reconhecimento jurídico da afetividade, 
igual grau de hierarquia jurídica dos vínculos de filiação biológicos e socioafetivos, bem como a possibilidade jurídica da multiparentalidade, os quais serão melhor detalhados a seguir. ${ }^{198}$

\subsection{RECONHECIMENTO JURÍDICO DA AFETIVIDADE}

\section{Conforme destaca Calderón ${ }^{199}$, a afetividade foi expressamente} mencionada por diversos Ministros em sua fundamentação, tendo havido uma ampla aceitação de seu reconhecimento jurídico pelo colegiado ao firmar a tese final em que o vínculo socioafetivo foi equiparado ao biológico para todos os efeitos.

Nesse sentido, cumpre mencionar um trecho do voto do relator, Ministro Luiz Fux, em que expressamente se refere à afetividade como uma das formas de filiação, ao lado do critério biológico e das presunções legais, vistos anteriormente:

"Se o conceito de família não pode ser reduzido a modelos padronizados, nem é lícita a hierarquização entre as diversas formas de filiação, afigura-se necessário contemplar sob o âmbito jurídico todas as formas pelas quais a parentalidade pode se manifestar, a saber: (i) pela presunção decorrente do casamento ou outras hipóteses legais (como a fecundação artificial homóloga ou a inseminação artificial heteróloga - art. 1.597, III a V do Código Civil de 2002); (ii) pela descendência biológica; ou (iii) pela afetividade. $" 200$

Destaca-se que a afetividade foi inclusive reconhecida como princípio pelo Ministro Celso de Mello, ou seja, não apenas em meio à significativa

\footnotetext{
198 CALDERÓN, Ricardo. Op. Cit. Disponível em: $<$ http://www.ibdfam.org.br/artigos/1155/Reflexos + da + decisão + do + STF + que + acolheu + a + socioafetivid soc $+\mathrm{e}+\mathrm{a}+$ multiparentalidade $>$. Acesso em 18 out. 2017.

199 Ibid. Disponível em: $<$ http://www.ibdfam.org.br/artigos/1155/Reflexos+da+decisão+do+STF+que+acolheu+a+socioafetivid soc $+\mathrm{e}+\mathrm{a}+$ multiparentalidade $>$. Acesso em 18 out. 2017.

${ }^{200}$ Supremo Tribunal Federal, Recurso Extraordinário n 898.060/SC, Rel. Min. Luiz Fux. Brasília, 21 set. 2016. Íntegra do voto do relator. p. 14-15. Disponível em: < http://www.stf.jus.br/arquivo/cms/noticiaNoticiaStf/anexo/RE898060.pdf $>$. Acesso em 25 out. 2017.
} 
doutrina, mas também jurisprudencialmente foi a ela atribuída natureza principiológica, como norteadora das relações familiares atuais. ${ }^{201}$

Além disso, com a referida decisão a paternidade socioafetiva se firmou como forma de parentesco civil, conforme dispõe o artigo 1.593 do CC/02, uma vez que se afirmou que a afetividade concorreria ao lado da consanguinidade, como parentesco de "outra origem", entendimento este já sustentado na doutrina e agora consagrado pelo Supremo Tribunal Federal.

Assim, pela tese fixada pelo Supremo Tribunal Federal, foi reconhecida, como consequência da afetividade, a paternidade socioafetiva, independentemente da realização de registro, uma vez que, para se concretizar, ela não precisaria ser formalizada, bastando "a consolidação do vínculo afetivo entre as partes ao longo do tempo, como sói ocorrer nos casos de posse do estado de filho." ${ }^{202}$

\subsection{IGUAL GRAU DE HIERARQUIA JURÍDICA DOS VÍNCULOS BIOLÓGICO E SOCIOAFETIVO}

Outro aspecto que se depreende desse julgamento histórico foi a afirmação do atual entendimento de inexistência de uma prevalência, a priori, do vínculo biológico ou socioafetivo, não assumindo este uma posição de paternidade de segunda categoria diante da paternidade biológica, mas sim equiparados hierarquicamente para todos os efeitos, de forma a possibilitar a multiparentalidade no ordenamento jurídico brasileiro. ${ }^{203}$

\footnotetext{
$201 \quad$ CALDERÓN, Ricardo. Op. $<$ http://www.ibdfam.org.br/artigos/1155/Reflexos+da+decisão+do+STF+que+acolheu+a+socioafetivid soc + e $+a+$ multiparentalidade $>$. Acesso em 18 out. 2017.

${ }^{202}$ Supremo Tribunal Federal, Recurso Extraordinário n 898.060/SC, Rel. Min. Luiz Fux, Brasília, 21 set. 2016. Íntegra do voto do relator. p. 16. Disponível em: $<$ http://www.stf.jus.br/arquivo/cms/noticiaNoticiaStf/anexo/RE898060.pdf>. Acesso em 25 de out. 2017.

${ }^{203}$ FERREIRA, Elisandra Alves. "Pai é quem cria!”: Filiação socioafetiva e seus reflexos. Revista IBDFAM: Família e Sucessões n. 21, mai.-jun. 2017. Belo Horizonte: IBDFAM, 2017. p. 83.
} 
Sendo assim, as visões jurisprudenciais anteriores ${ }^{204}$, segundo as quais haveria uma predominância da paternidade socioafetiva sobre a biológica, em casos de negatória de paternidade, ou ainda do vínculo biológico sobre o afetivo, nos casos de pedido judicial de reconhecimento de paternidade apresentados pelos filhos, demandam, atualmente, uma ponderação. Isso porque, após o julgamento do Supremo Tribunal Federal, para que se compreenda por uma eventual preferência filiatória, exige-se uma análise casuística, sempre observando o melhor interesse da criança ou adolescente envolvido.

Indubitavelmente, essa igualdade jurídica conferida aos vínculos biológico e socioafetivo prestigia não apenas o princípio da igualdade de filiação, mas também o princípio do melhor interesse da criança e adolescente, conforme ressaltado no seguinte trecho do voto do relator:

“(...) nos tempos atuais, descabe pretender decidir entre a filiação afetiva e a biológica quando o melhor interesse do descendente é o reconhecimento jurídico de ambos os vínculos. Do contrário, estar- se-ia transformando o ser humano em mero instrumento de aplicação dos esquadros determinados pelos legisladores. É o direito que deve servir à pessoa, não o contrário. $" 205$

Logo, o entendimento firmado pela Corte Constitucional foi de que pode haver o reconhecimento simultâneo de ambas as paternidades biológica e socioafetiva, "mesmo que haja o registro da paternidade/maternidade socioafetiva e, futuramente venha a ser descoberta a paternidade/maternidade biológica", como era a hipótese verificada no caso concreto julgado. ${ }^{206}$

\footnotetext{
${ }^{204}$ O Superior Tribunal de Justiça, para fins de estabelecer a prevalência de uma ou outra filiação, considerava o sujeito que tinha a iniciativa de postular em juízo, a constituição de novo vínculo ou sua desconstituição. Assim, caso se tratasse de uma ação negatória de paternidade proposta pelo pai registral ou seus herdeiros, dava-se prevalência à socioafetividade. Por outro lado, caso fosse uma ação de investigação de paternidade proposta pelo filho, prevalecia a parentalidade biológica.

${ }^{205}$ Supremo Tribunal Federal, Recurso Extraordinário n 898.060/SC, Rel. Min. Luiz Fux, Brasília, 21 set. 2016. Íntegra do voto do relator. p. 17. Disponível em: $<$ http://redir.stf.jus.br/paginadorpub/paginador.jsp?docTP=TP\&docID=13431919>. Acesso em 25 out. 2017.

${ }^{206}$ FERREIRA, Elisandra Alves. Op. Cit., p. 93.
} 


\subsection{POSSIBILIDADE JURÍDICA DA MULTIPARENTALIDADE}

Como último aspecto a ser destacado no julgamento do Recurso Extraordinário n 898.060/SC pelo Supremo Tribunal Federal, está a aceitação expressa da multiparentalidade, ou seja, a possibilidade de múltiplos vínculos de filiação concomitantes, mesmo contra a vontade do pai biológico ou do pai socioafetivo. $^{207}$

Na realidade, a admissibilidade jurídica da multiparentalidade nada mais é do que uma conclusão lógica dos demais aspectos extraídos do referido julgado, uma vez que a atribuição de efeitos jurídicos à afetividade e a afirmação de igual grau de hierarquia entre os vínculos biológico e socioafetivo, consequentemente, viabilizam o reconhecimento da multiparentalidade.

Assim, em seu voto, o Ministro Luiz Fux, firmou o entendimento de que os princípios da dignidade da pessoa humana (artigo $1^{\circ}$, III, CF/88) e da paternidade responsável (artigo 226, § $7^{\circ}, \mathrm{CF} / 88$ ) impõem o reconhecimento de modelos familiares diversos da concepção tradicional, devendo o ordenamento jurídico acolher tanto vínculos de filiação construídos com base no afeto, quanto àqueles originados da ascendência biológica.

Destacou ainda que "a omissão do legislador brasileiro quanto ao reconhecimento dos mais diversos arranjos familiares não pode servir de escusa para a negativa de proteção a situações de pluriparentalidade" ${ }^{208}$, sendo imprescindível à adequada tutela da pessoa humana que se reconheça, com todos os seus efeitos, os vínculos parentais de origem afetiva e biológica.

\footnotetext{
${ }^{207}$ TARTUCE, Flávio. 2016: O ano da afetividade na jurisprudência superior brasileira. Disponível em: $<$ http://www.ibdfam.org.br/artigos/1178/2016\%3A+O+ano+da+afetividade+na+jurisprud $\% \mathrm{C} 3 \% \mathrm{~A}$ Ancia+superior+brasileira>. Acesso em 25 out. 2017.

${ }^{208}$ Supremo Tribunal Federal, Recurso Extraordinário n 898.060/SC, Rel. Min. Luiz Fux, Brasília, 21 set. 2016. Íntegra do voto do relator. p. 18. Disponível em: $<$ http://redir.stf.jus.br/paginadorpub/paginador.jsp?docTP=TP\&docID=13431919>. Acesso em 25 out. 2017.
} 
Cumpre ressaltar, entretanto, que tal decisão do Supremo Tribunal Federal não foi pioneira em admitir a pluriparentalidade, uma vez que já se observava um posicionamento na doutrina e em algumas decisões judiciais, anteriores ao julgamento da Corte Suprema, favoráveis à multiparentalidade, havendo inclusive o Enunciado n ${ }^{\circ} 09$ do IBDFAM que a ela também já atribuía efeitos jurídicos.

No entanto, a fixação desse entendimento pela Corte Constitucional do país possui, inegavelmente, uma grande relevância jurídica, já que será capaz de repercutir de maneira mais efetiva no sentido de promover uma maior aceitação dessa nova entidade familiar que, aos poucos, vai ganhando cada vez mais espaço no ordenamento jurídico brasileiro.

\subsection{POSSÍVEIS REFLEXOS DO JULGAMENTO}

Após essa paradigmática decisão proferida pelo Supremo Tribunal Federal, algumas problemáticas envolvendo o reconhecimento do instituto da multiparentalidade pela Corte Suprema passaram a ser suscitadas, motivo pelo qual destacaremos a seguir algumas dessas reflexões surgidas a partir do referido julgamento.

Inicialmente, cogita-se que a tese fixada pela Corte Constitucional, no sentido de admitir o reconhecimento de vínculo biológico, independentemente da existência de vínculo socioafetivo, poderia dar ensejo a um crescente número de demandas mercenárias, que busquem o reconhecimento da paternidade biológica por interesses meramente patrimoniais.

No entanto, como bem ressalta Schreiber ${ }^{209}$, não se trata de uma situação instransponível, cabendo aos juízes e tribunais, no julgamento do caso concreto, empregar as salvaguardas existentes dentro do próprio sistema

\footnotetext{
209 SCHREIBER, Anderson. Op. Cit. Disponível em: $<$ http://www.cartaforense.com.br/conteudo/artigos/stf-repercussao-geral-622-a-multiparentalidade-eseus-efeitos/16982>. Acesso em 24 out. 2017.
} 
jurídico brasileiro, como é o caso do princípio da boa-fé objetiva ou ainda, especificamente quanto ao direito aos alimentos, do binômio necessidadepossibilidade, evitando o enriquecimento ilícito dos envolvidos em uma multiparentalidade.

Além disso, João Aguirre ${ }^{210}$ destaca que a tese firmada pelo Supremo Tribunal Federal apresenta ainda incongruências dentro do próprio sistema legal, seja no que tange ao instituto da adoção, em que se poderia cogitar da possibilidade de um filho adotivo pleitear uma dupla paternidade; ou ainda quanto ao instituto da reprodução assistida heteróloga, onde o provimento 52 da Corregedoria Nacional de Justiça ${ }^{211}$ acabou com o anonimato do doador genético, podendo-se questionar de eventual demanda contra este, visando reconhecê-lo como pai biológico, ao lado do pai socioafetivo.

Por isso, sustenta o autor que a multiparentalidade somente poderia ser reconhecida quando presente a afetividade em todas as relações consideradas, ou seja, não apenas para a configuração do vínculo de socioafetividade, mas também nas relações com o genitor. Logo, não seria em todo e qualquer caso que haveria uma coexistência entre os vínculos socioafetivo e biológico, evitando-se, assim, aquelas demandas frívolas que buscassem interesses meramente materiais, quando ausente relação de afeto entre as partes.

Sendo assim, segundo esse entendimento, seria admissível o estabelecimento de vínculos simultâneos e, consequentemente, da multiparentalidade, apenas quando também comprovada a socioafetividade entre o pai biológico e o filho. Caso contrário, entende-se que permanece o

\footnotetext{
${ }^{210}$ AGUIRRE, João. Reflexões sobre a multiparentalidade e a repercussão Geral 622 do STF. p. 286. Disponível em: $<$ http://www.revistas.unilasalle.edu.br/index.php/redes/article/view/3670/pdf $>$. Acesso em 25 out. 2017.

$211 \quad$ Provimento $\quad \mathrm{n}^{\circ} \quad 52 \quad$ CNJ. $\quad$ Disponível em: $<$ http://www.cnj.jus.br/files/conteudo/arquivo/2016/03/6bd953c10912313a24633f1a1e6535e1.pdf>. Acesso em 26 out. 2017.
} 
direito à identidade de conhecer a ascendência genética, mas tal direito não implicará em a ela atribuir os efeitos decorrentes das relações de parentesco, o que solucionaria àquelas questões levantadas quanto à adoção e reprodução assistida heteróloga.

O Ministro Edson Fachin chegou a suscitar em seu voto essa distinção entre a figura de genitor (ascendente genético) e a função do pai, o que, entretanto, não chegou a ser fixado na tese final. Como bem destaca Calderón $^{212}$, essa é uma questão que vai seguir em pauta para seu melhor esclarecimento, cabendo à doutrina digerir o resultado do julgamento a partir de então.

Por fim, cumpre ressaltar o recente julgamento realizado pelo Superior Tribunal de Justiça que, na esteira do entendimento firmado pelo Supremo Tribunal Federal, concretizou a tese firmada sobre a multiparentalidade.

No caso concreto, foi garantido a um idoso de quase 70 (setenta) anos o direito a receber herança do pai biológico, mesmo já tendo recebido o patrimônio de seu pai socioafetivo. O colegiado decidiu que a relação filial socioafetiva não impediria o reconhecimento de sua ancestralidade, com todos os efeitos patrimoniais decorrentes. $\mathrm{O}$ que gerou certa perplexidade foi a notícia de que o autor teria tomado conhecimento de sua origem biológica em 1981, tendo apenas em 2008 ingressado com a ação, mas, conforme afirmado pela Ministra Nancy Andrighi, "pode-se especular o porquê da demora do autor na busca pelo reconhecimento da paternidade biológica, mas não se pode negar os efeitos dela, uma vez comprovada."213

\footnotetext{
212 CALDERÓN, Ricardo. Op. Cit. Disponível em: $<$ http://www.ibdfam.org.br/artigos/1155/Reflexos + da + decisão+do+STF+que+acolheu + a + socioafetivid soc $+\mathrm{e}+\mathrm{a}+$ multiparentalidade $>$. Acesso em 18 out. 2017.

213 IBDFAM. Notícia. Decisão concretiza tese firmada pelo STF sobre a multiparentalidade. Publicada em 29 mar. 2017. Disponível em: < http://www.ibdfam.org.br/noticias/6244>. Acesso em 26 out. 2017.
} 


\section{CONCLUSÃO}

Conforme já exaustivamente destacado, percebe-se que a sociedade está em constante evolução e novos direitos reivindicam reconhecimento, devendo o ordenamento jurídico se adequar à realidade social e não o oposto, sob pena de petrificação dos institutos e consequente defasagem legal.

Verificamos, pelo presente estudo, que a família do século XXI é uma família plural e multifacetária, que valoriza, sob a ótica da atual Constituição Federal, a liberdade, a igualdade e a fraternidade, como forma de realização pessoal e garantia da dignidade de seus membros, passando este a ser seu objetivo precípuo. $^{214}$

Assim, são priorizados os interesses da criança e do adolescente como sujeitos de direito, dando-se prevalência à dignidade das pessoas, em abandono à visão primordialmente patrimonialista que vigia anteriormente.

Sob a égide da Constituição de 1988, vimos que foi vedado também qualquer tratamento discriminatório quanto à origem da filiação, seja ela biológica ou socioafetiva, todas se encontrando em patamar de igualdade, com o reconhecimento de todos os efeitos jurídicos delas decorrentes.

Isso porque, no âmbito do Direito de Família, cada caso envolve inúmeras variáveis a serem observadas, então não há como afirmar a prevalência, em abstrato, de qualquer critério de filiação sobre outro, uma vez que a análise do caso em específico pode demonstrar que a melhor solução não seria a predominância de uma apenas, mas de todas, convivendo em igualdade de condições e dando ensejo ao fenômeno da multiparentalidade.

\footnotetext{
214 NAHAS, Luciana Faisca. A construção horizontal das relações familiares: um novo paradigma jurídico. Revista IBDFAM: Famílias e Sucessões n. 14, mar.-abr. 2016. Belo Horizonte: IBDFAM, 2016. p. 83.
} 
Isto posto, o reconhecimento da possibilidade da multiparentalidade nada mais é do que resultado das diversas transformações vivenciadas na esfera das famílias nas últimas décadas, que se consolidou como fenômeno cultural, na medida em que prescinde da existência de vínculos biológicos entre seus membros e não se limita a modelos pré-concebidos.

Em que pese o Supremo Tribunal Federal ter admitido a multiparentalidade no julgamento do Recurso Extraordinário no ${ }^{\circ} 898.060 / \mathrm{SC}$, algumas questões jurídicas no âmbito do Direito de Família permaneceram em aberto, como é o caso do exercício do poder familiar, do direito de guarda e visitação e da obrigação alimentar, diante de uma multiplicidade de vínculos de filiação.

No entanto, conforme visto, as soluções apresentadas pela doutrina e jurisprudência suprem essa ausência de regramento legal específico quanto aos efeitos de uma pluriparentalidade, o que demonstra a plena viabilidade de compatibilização desse instituto dentro do ordenamento jurídico brasileiro.

Ademais, não há qualquer impedimento legal ao reconhecimento da multiparentalidade, sendo necessário apenas uma adequação das regras aplicáveis à biparentalidade a este novo contexto de múltiplos vínculos parentais.

Destaca-se, por fim, que o julgamento realizado pelo Supremo Tribunal Federal contribuiu para uma maior aproximação entre a realidade social e o Direito, consagrando juridicamente laços faticamente já existentes e permitindo a máxima visibilidade necessária a esse instituto.

Pode-se dizer que a tendência, a partir de agora, será o surgimento de cada vez mais decisões reconhecendo a possibilidade de uma multiplicidade parental e, talvez, se continuarmos nesse caminho, em algum momento alcançaremos o pleno reconhecimento da multiparentalidade para que assuma, 
na prática, patamar de igualdade com as demais entidades familiares já concebidas. 


\section{BIBLIOGRAFIA}

AGUIRRE, João. Reflexões sobre a multiparentalidade e a repercussão Geral 622 do STF. Disponível em:

$<$ http://www.revistas.unilasalle.edu.br/index.php/redes/article/view/3670/pdf $>$. Acesso em 25 out. 2017.

ALBUQUERQUE, Fabíola Santos. Poder familiar nas familias recompostas e o artigo 1636 do CC/02. Disponível em: $<$ http://www.ibdfam.org.br/_img/congressos/anais/117.pdf $>$. Acesso em 14 set. 2017.

BRASIL. Conselho da Justiça Federal. Enunciados aprovados na I, III, IV, V Jornadas de Direito Civil. Disponível em: <http://www.cjf.jus.br/cjf/CEJCoedi/jornadas-cej/enunciados-aprovados-da-i-iii-iv-e-v-jornada-de-direitocivil/compilacaoenunciadosaprovados1-3-4jornadadircivilnum.pdf/view $>$. Acesso em 05 out. 2017.

BRASIL. Conselho Nacional de Justiça. Atos Normativos. Provimento $\mathrm{n}^{\circ} 2$ de 27 abr. 2009. Disponível em: $<$ http://www.cnj.jus.br///images/atos_normativos/provimento/provimento_2_2 7042009_26102012180800.pdf>. Acesso em 15 set. 2017.

BRASIL. Conselho Nacional de Justiça. Atos Normativos. Provimento ${ }^{\circ} 52$ de 14 mar. 2016. Disponível em: $<$ http://www.cnj.jus.br/files/conteudo/arquivo/2016/03/6bd953c10912313a246 33f1a1e6535e1.pdf $>$. Acesso em 26 out. 2017.

BRASIL. Conselho Nacional de Justiça. Resolução n 175 de 14 mai. 2013. Disponível em: <http://www.cnj.jus.br/busca-atos-adm?documento=2504>. Acesso em 30 mai. 2017. 
BRASIL. Constituição da República Federativa do Brasil: promulgada em 05 de outubro de $1988 . \quad$ Disponível em: $<$ http://www.planalto.gov.br/ccivil_03/constituicao/constituicao.htm>.

BRASIL. IBDFAM. Enunciados $\mathrm{n}^{\circ} \quad 06,07$ e 09 . Disponível em: $<$ http://www.ibdfam.org.br/noticias/5819/IBDFAM+aprova+Enunciados $>$. Acesso em 07 de out. 2017.

BRASIL. Lei n. 6.015, de 31 de dezembro de 1973. Dispõe sobre os registros públicos, e dá outras providências. Disponível em: $<$ http://www.planalto.gov.br/ccivil_03/leis/L6015original.htm>.

BRASIL. Lei n. 10.406, de 10 de janeiro de 2002. Institui o Código Civil. Disponível em: < http://www.planalto.gov.br/ccivil_03/leis/2002/110406.htm>.

BRASIL. Projeto de Lei ${ }^{\circ}$ 2.285/07, de 25 de outubro de 2007. Dispõe sobre o Estatuto das Famílias. Disponível em: < http://www.camara.gov.br/proposicoesWeb/prop_mostrarintegra;jsessionid=79 AC192A2336C4CFDF8CE57351D70946.proposicoesWebExterno1?codteor= $517043 \&$ filename $=\mathrm{PL}+2285 / 2007>$.

BRASIL. Projeto de Lei ${ }^{\circ}$ 470/13, de 12 de novembro de 2013. Dispõe sobre o Estatuto das Famílias e dá outras providências. Disponível em: $<$ https://legis.senado.leg.br/sdleg-getter/documento?dm=4590857>.

CALDERÓN, Ricardo. Reflexos da decisão do STF que acolheu a socioafetividade $e$ a multiparentalidade. Disponível em: $<$ http://www.ibdfam.org.br/artigos/1155/Reflexos+da+decisão+do+STF+que+ acolheu $+\mathrm{a}+$ socioafetividade $+\mathrm{e}+\mathrm{a}+$ multiparentalidade $>$. Acesso em 18 out. 2017.

CASSETTARI, Christiano. Multiparentalidade e parentalidade socioafetiva: efeitos jurídicos. $3^{\text {a }}$ ed.. São Paulo: Atlas, 2017. 285 p. 
DIAS, Maria Berenice. Manual de Direito das Famílias. 10 ${ }^{\mathrm{a}}$ ed.. São Paulo: Revista dos Tribunais, 2015. $752 \mathrm{p}$.

FARIAS, Cristiano Chaves de; ROSENVALD, Nelson. Curso de Direito Civil: Vol. 6 Famílias. $7^{\text {a }}$ ed.. São Paulo: Atlas, 2015. 1024 p.

FERREIRA, Elisandra Alves. "Pai é quem cria!": Filiação socioafetiva e seus reflexos. Revista IBDFAM: Família e Sucessões, n. 21, mai.jun. 2017. Belo Horizonte: IBDFAM, 2017. p. 83-98.

IBDFAM. Notícia. Decisão concretiza tese firmada pelo STF sobre a multiparentalidade. Publicada em 29 mar. 2017. Disponível em: < http://www.ibdfam.org.br/noticias/6244>. Acesso em 26 de out. 2017.

LÔBO, Paulo. Direito Civil: Famílias. 5a ed.. São Paulo: Saraiva, 2014. 397 p.

MADALENO, Rolf. Curso de Direito de Família. $4^{\mathrm{a}}$ ed.. Rio de Janeiro: Editora Forense Ltda., 2011. 1211 p.

MADALENO, Rolf. Laços que ficam e paternidade alimentar. Disponível em: $\quad<$ http://www.rolfmadaleno.com.br/novosite/conteudo.php?id=998>. Acesso em 23 out. 2017.

NAHAS, Luciana Faisca. A construção horizontal das relações familiares: um novo paradigma jurídico. Revista IBDFAM: Famílias e Sucessões, n. 14, mar.abr. 2016. Belo Horizonte: IBDFAM, 2016. p. 75-97.

PAIANO, Daniela Braga. A Família Atual e as Espécies e Filiação: Da Possibilidade Jurídica da Multiparentalidade. Rio de Janeiro: Lumen Juris, 2017. $224 \mathrm{p}$.

PENNA, Saulo Versiani; ARAUJO, Deborah Nayara dos Reis. Famílias brasileiras reconstituidas e a multiparentalidade: adequação do direito à 
realidade socioafetiva. Revista IBDFAM: Famílias e Sucessões, n. 21, mai.jun. 2017. Belo Horizonte: IBDFAM, 2017. p. 27-43.

PEREIRA, Caio Mário da Silva. Instituições de Direito Civil: Volume V Direito de Família. 23 ${ }^{\mathrm{a}}$ ed.. Rio de Janeiro: Forense, 2015. 727 p.

PLENO: Paternidade socioafetiva não exime de responsabilidade o pai biológico (2/2). Supremo Tribunal Federal. Brasília: TV Justiça, 22 set. 2016. $121 \mathrm{~min}$.

Disponível

em:

$<$ https://www.youtube.com/watch?v=vMgMQ0DdVbE $>$. Acesso em 20 out. 2017.

SCHREIBER, Anderson. STF, Repercussão Geral 622: a Multiparentalidade e seus Efeitos. Disponível em:

$<$ http://www.cartaforense.com.br/conteudo/artigos/stf-repercussao-geral-622a-multiparentalidade-e-seus-efeitos/16982>. Acesso em 24 out. 2017.

SCHREIBER, Anderson; LUSTOSA, Paulo Franco. Efeitos Jurídicos da multiparentalidade. Revista Pensar. Fortaleza, v. 21, n. 3, set.-dez. 2016. p. 847-873.

Superior Tribunal De Justiça, Recurso Especial n 1.183.378/RS, Rel. Min. Luís Felipe Salomão, Brasília, 25 out. 2011.

Superior Tribunal de Justiça, Recurso Especial $n^{\circ}$ 1.217.415/RS, Rel. Min. Nancy Andrighi, Brasília, 19 jun. 2012.

Supremo Tribunal Federal, ADPF n 132/RJ, Rel. Min. Ayres Britto, Brasília, 05 mai. 2011.

Supremo Tribunal Federal, Recurso Extraordinário n 898.060/SC, Rel. Min. Luiz Fux, Brasília, 21 set. 2016. Íntegra do voto do relator. Disponível em: < 
http://www.stf.jus.br/arquivo/cms/noticiaNoticiaStf/anexo/RE898060.pdf>. Acesso em 25 out. 2017.

Supremo Tribunal Federal, Informativo $\mathrm{n}^{\circ}$ 840. Disponível em: $<$ http://www.stf.jus.br/arquivo/informativo/documento/informativo840.htm $>$. Acesso em 25 out. 2017.

Tribunal de Justiça do Rio Grande do Sul, Apelação Cível $\mathrm{n}^{\circ}$ 70040743338/RS, Rel. Luiz Felipe Brasil Santos, Porto Alegre, 12 mai. 2011.

Tribunal de Justiça do Estado da Bahia, Apelação Cível n 0513463 46.2014.8.05.0001, Rel. Des. Dinalva Gomes Laranjeira Pimentel, Salvador, 01 set. 2015.

Tribunal de Justiça do Estado do Paraná, Autos $\mathrm{n}^{\circ}$ 003895854.2012.8.16.0021, Juiz Dr. Sérgio Luiz Kreuz, Cascavel, 20 fev. 2013.

TARTUCE, Flávio. Breves e iniciais reflexões sobre o julgamento do STF sobre parentalidade socioafetiva. Disponível em: < https://flaviotartuce.jusbrasil.com.br/noticias/387075289/breves-e-iniciaisreflexoes-sobre-o-julgamento-do-stf-sobre-parentalidade-socioafetiva> . Acesso em 13 out. 2017.

TARTUCE, Flávio. 2016: $O$ ano da afetividade na jurisprudência superior brasileira. Disponível em: < http://www.ibdfam.org.br/artigos/1178/2016\%3A+O+ano+da+afetividade+na+ jurisprud\%C3\%AAncia+superior+brasileira>. Acesso em 25 out. 2017.

TARTUCE, Flávio; SIMÃO, José Fernando. Direito Civil: Vol. 5 Direito de Família. $7^{a}$ ed.. São Paulo: Método, 2012. 540 p. 
TEIXEIRA, Ana Carolina Brochado; RODRIGUES, Renata de Lima. A multiparentalidade como nova estrutura de parentesco na contemporaneidade. Revista Brasileira de Direito Civil, volume 4, abr.-jun. 2015. p. 9-38.

WELTER, Belmiro Pedro. Teoria tridimensional no Direito de Familia: reconhecimento de todos os direitos das filiações genética e socioafetiva. Decisão comentada do Tribunal de Justiça do Rio Grande do Sul. Disponível em:

http://www.amprs.org.br/arquivos/revista_artigo/arquivo_1246467677.pdf>. Acesso em 16 out. 2017. 